\title{
Adam Smith's Approach to Public Policy: Astounding Deviation or Artful Moderation?
}

\author{
By: Michael J. Clark
}

Author byline: Michael Clark is a Visiting Assistant Professor at the University of Baltimore. His email is mclark4@gmail.com and his website is mclarkphd.blogspot.com

\begin{abstract}
:
Recent academic work has attempted to change the interpretation of Adam Smith from the founder of free market economics to a proponent of something much more akin to the modern welfare state. In a well known article Jacob Viner even claims that Smith's departures from liberty were so great that an index of them would have astounded Smith. I suggest that Smith's polite rhetorical strategy - represented by his explicit praise of the moderate rule Solon - has been under-appreciated. This paper aims to examine the Wealth of Nations with Smith's polite approach in mind. I show that Smith's interventionism was more limited than some suggest, and that some of the interventions contravened the liberty principle only mildly. I also show that virtually all of the interventions entertained or endorsed by Smith were part of the status quo in Scotland at the time. The approach also provides potential explanations for some of Smith's well known inconsistencies, such as his endorsement of restriction in banking and lending at interest.
\end{abstract}

JEL CODES: B12, H11, B41

Keywords: Adam Smith, Public Policy, Liberty, Government Intervention, Rhetoric 
He nowhere gathered together in orderly fashion the exceptions which he would have made to his general restriction of government activity... If he had been brought face to face with a complete list of the modifications to the principle of laissez faire to which he at one place or another had granted his approval, I have no doubt that he would have been astounded at his own moderation.

- Jacob Viner

\section{Section 1: Introduction}

Adam Smith, the father of free-market economics, put forth some form of support for eighteen different government interventions in the Wealth of Nations. It seems quite evident that Adam Smith was not a harsh, simplistic, doctrinaire believer in free markets. There is nothing new in saying that Smith's belief in liberty had depth to it. Smith's willingness to deviate from the liberty principle has been explored from numerous angles, and inferences about his politics are plenty. The lack of perfection in Smith's system of natural liberty has been highlighted in various articles on the Das Adam Smith problem ${ }^{1}$, Smith's view of the legislature ${ }^{2}$, social democratic readings of $\mathrm{Smith}^{3}$, and even Smith's own religious views. From Jacob Viner, to George Stigler, and now Emma Rothschild and others, the Smithian literature often emphasizes Smith's departures from laissez faire.

$W N$ is a nuanced tract that pursues liberty as a maxim and not an axiom. Smith believed in a presumption of liberty. The presumption of liberty is an approach that is founded on the idea that liberty works so well, and in so many instances, that one should presume liberty is the correct policy unless there is overwhelming proof to the contrary.

\footnotetext{
${ }^{1}$ For more information see Teichgraeber III (1981)

2 See Stigler (1965)

${ }^{3}$ See McLean (2006)
} 
One needs to prove why liberty does not work in particular instances, and not vice versa. Smith was willing to talk about the cases where there may be ample evidence contradicting the idea of liberty in practice. He didn't shy away from stating his judgments on such matters. Smith's not following his ideas on liberty to a One Hundred percent support has caused many to analyze his departures from liberty. Jacob Viner even claims that the departures were so great that an index of them would have made Smith himself "astounded at his own moderation" (Viner 1927, 218).

But, Adam Smith was a careful author ${ }^{4}$. His longstanding attention and study of writing style and rhetoric make it a bit of a challenge to see Smith as a great scholar and one who was unaware of his own approach and moderation. Would Smith really be astounded at his own moderation? Is there any explanation for his moderation in public policy issues?

When analyzing the support of interventionist policies in WN Smith's strategic approach to writing has been under-appreciated. Smith found great virtue in putting forth ideas in ways that accommodated, when necessary, the bias opposed to them (Clark 2011; Smith 1776). And, for Smith there would be times when it was necessary. He was a radical in the face of much deep-seated opposition. Smith considered his audience in his writing, and it is obvious that Smith may have adjusted his rhetoric because he wanted to be careful with how his words were received. Smith's support for a cautious strategic approach in the face of opposition is his attempt to counter arrogance. One of the main themes that ran through all of his work is that ignorance often manifests itself as

\footnotetext{
${ }^{4}$ See Fleischacker (2004)
} 
arrogance. Smith abhorred arrogance and understood that he was not exempt from the temptation that all face - the temptation to overvalue one's mastery in ideas and thought. Smith not only believed in expressing a cautious strategic approach, but it seems likely he also attempted to take such an approach. Certainly, an understanding of how facing strong ideological opposition impacted his writing is an important aspect of analyzing Smith's policy views.

When facing ideological opposition, Smith admired the strategic approach of Solon. The approach, explored in Clark (2011), required one to accommodate one's more extreme views to the prejudice of the public. The aim would be to put forth a system that one believed in yet still achieved "the best that the people can bare" (Smith $1779,233)$. If Smith really followed this strategic approach we could expect to see moments of inconsistency, writing between the lines, rationalizations, and concessions to the status quo that Smith was challenging. At the very least one should be able to see some remnants of Smith's attempt to fudge, bend, and compromise his radical views to make them work with the prejudice of his day. This paper will examine how well Smith's interventionist policy prescriptions fit with these tendencies of a Solonesque writer.

If one acknowledges Smith's approach to strategic compromise it does not require one to interpret Smith as compromising every time he suggested a contravention of natural liberty. In looking at Smith's policy prescriptions it is clear that Smith was not an advocate of a system that follows the liberty principle $100 \%$. However, if we read the $W N$ without any attention to his strategic approach it would be easy to conclude that 
Adam Smith had a sincere adherence to liberty in some range $\mathrm{X} \%$ of relevant cases, where $\mathrm{X}$ is large enough to say that there is a presumption of liberty. Once we consider Smith's strategic approach it becomes very plausible that Smith sincerely felt that liberty worked in $\mathrm{X}+\mathrm{N} \%$ of the cases, where $\mathrm{N}$ is some additional amount that Smith was disinclined to further affirm clearly, but nonetheless favored. The distance between $\mathrm{X}$ and $\mathrm{N}$ would represent the amount Smith decided to soften the pitch of his argumentation as a result of his desire to observe the prejudice of his day. Maybe Adam Smith would be astounded if he saw a list of all the interventions he supported in some way. But, it also seems likely that the list of interventions is large as a result of a certain level of politeness and respect for the status quo.

To determine if Smith's policy views show aspects of the Solonesque approach, it will be necessary to analyze many aspects of Smith's policy prescriptions. To start, the interventions Smith supported will be delineated and sifted through. The level of support and definiteness with which Smith supported the interventions will be catalogued. The overview of Smith's interventionist support will show that Smith did bring out a number of contraventions of natural liberty. However, the interpretation of Smith as an unambiguous supporter of these interventions will start to be questioned. The moderate level of support, moments of waffling, and even blatant objections to his own interventionist recommendations make one start to wonder if Adam Smith left a little wiggle room in $W N$ for mollifying the public bias.

Once the potential for seeing the Solon in Smith's policy prescriptions is established, three additional lines of evidence will be examined. First, in a number of 
cases where Smith calls for a break with natural liberty he does so using reasoning that he fits into the overall liberal cause. His arguments for these exceptions to natural liberty seem sincere, but he still tries to provide some affirmation of a liberty principle. Second, it will be argued that some of Smith's inconsistencies come as a result of Smith moving from challenging foundational issues to bargaining with particular policies. And finally,

Smith's interventionist recommendations will be compared with the status quo policies of Scotland and Britain. The policy comparisons with the status quo help us analyze the focus of his departures from laissez faire when discussing specific policies. Overall, the evidence lends support to the view that Smith's support of interventions is easily overstated. Adam Smith's Solonesque approach, with a desire to make his views palatable to those biased against him, has been overlooked in modern literature.

\section{Section 2: Indexing the Interventions}

To start the analysis of how, or if, Smith followed the approach of Solon in his public-policy prescriptions, I catalog his policy judgments. The cataloguing provides an easy reference to the material and a basic orientation for just how firm Smith's support was for each intervention he supported. The overview of Smith's support of interventions will show a number of contraventions of natural liberty that have been emphasized and dissected by scholars over the centuries. However, I will argue against the interpretation of Smith as an unambiguous supporter of these interventions.

The list of interventions is from Viner (1927). In the famous article Viner highlights Smith's interventionist ideas. Viner suggests that many forget the 
interventionist side of Smith and that Smith himself would be astounded at a list of claims against liberty. In the end, Viner does come to the conclusion that although Smith has moments of interventionist suggestions, he should still be considered to hold a presumption that liberty is best unless proved otherwise. The interventionist suggestions Viner highlights are the most commonly referenced interventions in the Smithian literature. All matters of taxation are granted as interventionist, but not under consideration in this analysis. Many authors who examine Smith's interventionist side do not rely on Smith's analysis of tax revenues for their conclusions. The catalogue of interventions utilizes a coding system that ranks the interventions. In some respect, the ranking tracks the definiteness with which Smith supports the interventions. The range varies from explicit support to an acceptance of the contravention only as a concession. The coding ranges through six categories; a coding of six is the strongest and clearest support of the intervention, whereas a lower coding involves weakening support for the intervention.

The coding is not claimed to coincide perfectly with Smith's level of approval of the interventions. An intervention coded as a level of three could be an intervention that Smith respects more than some interventions that are ranked as a five. Although the ranking system is not perfect it does provide a general feeling for Smith's various levels of support and it provides a launching pad from which to analyze the openings for Solonesque compromises in Smith's interventionist claims. 
Table 1 lists each intervention that Smith supported. The pages listed are pages in

$W N$ where Smith discusses the intervention. (The page numbering corresponds to the

Oxford University Press/Liberty Fund edition edited by Campbell, Skinner, and Todd.)

Rankings for Smith's Level of Support of the Intervention:

6 - Unequivocal Support

5 - Explicit Support of the Intervention but with Limited Scope

4 - Fuzzy, Non-Explicit, Tentative, or Mixed Support of the Intervention

3 - Little Support or Objection

2 - Support with Serious Objection to the Intervention

1 - Argued Against the Contravention but Accepted it as a Concession

Table 1: Interventions in WN Catalogued by Smith's Level of Support

\begin{tabular}{|c|c|c|c|c|c|c|c|}
\hline & & \multicolumn{6}{|c|}{ Coded Level of Support } \\
\hline Intervention & Pages & 6 & 5 & 4 & 3 & 2 & 1 \\
\hline $\begin{array}{c}\text { Canals and } \\
\text { Harbors }\end{array}$ & $\begin{array}{l}163-164,724- \\
731,756-758\end{array}$ & $\mathrm{X}$ & & & & & \\
\hline Coinage & $\begin{array}{c}61-64,301- \\
303,478-480 \\
549-555,724\end{array}$ & $\mathrm{X}$ & & & & & \\
\hline $\begin{array}{l}\text { Corn Export } \\
\text { Restrictions }\end{array}$ & $524-543$ & & & & & & $\mathrm{X}$ \\
\hline Education & $758-815$ & & & $\mathrm{X}$ & & & \\
\hline High Roads & $724-731$ & $\mathrm{X}$ & & & & & \\
\hline $\begin{array}{l}\text { Joint Stock } \\
\text { Companies }\end{array}$ & $732-758$ & & $\mathrm{X}$ & & & & \\
\hline Leprosy & $787-788$ & & & & $\mathrm{X}$ & & \\
\hline $\begin{array}{c}\text { Mortgage } \\
\text { Registration }\end{array}$ & 863 & & & $\mathrm{X}$ & & & \\
\hline Navigation Acts & $\begin{array}{c}463-465,577- \\
584,589-599 \\
614\end{array}$ & & & & & $\mathrm{X}$ & \\
\hline Options Clause & $325-329$ & $\mathrm{X}$ & & & & & \\
\hline Party Walls & 324 & $\mathrm{X}$ & & & & & \\
\hline Payment-In-Kind & $157-158$ & $\mathrm{X}$ & & & & & \\
\hline Post Office & 724,818 & & & & $\mathrm{X}$ & & \\
\hline Roads & $\begin{array}{c}163-164,724- \\
731,815\end{array}$ & & & & & & \\
\hline $\begin{array}{c}\text { Small } \\
\text { Denomination } \\
\text { Notes }\end{array}$ & $320-329$ & $\mathrm{X}$ & & & & & \\
\hline $\begin{array}{l}\text { Strategic } \\
\text { Material } \\
\text { Bounties }\end{array}$ & $522-533$ & & & & & & \\
\hline Temporary & $733,754-755$ & $\mathrm{X}$ & & & & & \\
\hline
\end{tabular}




\begin{tabular}{|c|c|c|c|c|c|c|c|}
\hline & & \multicolumn{7}{|c|}{ Coded Level of Support } \\
\hline Intervention & Pages & $\mathbf{6}$ & $\mathbf{5}$ & $\mathbf{4}$ & $\mathbf{3}$ & $\mathbf{2}$ & $\mathbf{1}$ \\
\hline Monopolies & & & & & & & \\
\hline Usury & $350-359$ & $\mathrm{X}$ & & & & & \\
\hline
\end{tabular}

\section{Section 2, Part A: Explicit Support}

As one can see from Table 1, Adam Smith provided unequivocal support for nine interventions. These interventions are the cases where Smith most clearly put forth his support for a specific government intervention in $W N$. They are not severely limited in scope or presented in a transparently contentious or waffling manner. The nine unequivocally supported interventions are given a rank of six in table 1. Although nine explicitly supported interventions may seem like a large number to some, what is more striking about the list of nine is the interventions that do not appear. When Smith's interventionist support is explored, generally it is taken for granted that all eighteen are explicitly and unequivocally promoted.

\section{Section 2, Part B: Interventions with a Limited Scope}

The slide away from explicit support starts with what I have labeled a rank five intervention. Here Smith explicitly backs an intervention, but with a rather limited scope. This category only contains Smith's discussion on joint stock companies.

Smith perceived joint-stock companies as privileged companies. Part of the privilege Smith feels the joint-stock companies hold is their legal ability to be held to limited liability. Smith also feels that the structure and setup of joint-stock companies often ends in additional political privileges. He distinguished them from private co- 
partneries and ties them to government dealings by noting that they are established by a royal charter or act of parliament. At the foundation of Smith's support of the intervention is the presumption that joint-stock companies come in to being by an act of the political system. The sovereign's ability to pick and choose which companies can be joint-stock companies naturally ties in to Smith's concerns for government created privileges.

Smith goes through many examples to show the privileges that often come with joint-stock companies. He explains how the Royal African Company had private competition and yet through political action a heavy tax was placed on the private competition. The private competition still made it difficult for the Royal African Company to survive and thus another act of parliament was necessary to back the creditors of the company (Smith 1776, 742 -743). There is an evolutionary tendency for a company that starts by government decree, such as a joint-stock company, to eventually rely on privileges from the state.

For Adam Smith, joint-stock companies were often just another way in which individuals tried to use the political system for gain. His rhetoric on joint-stock companies ties in closely to a general theme throughout $W N$. Smith feels that the creation of wealth cannot be planned by man regardless of how pure his intentions are. For Smith, when one attempts to plan the creation of wealth for a society it often cause more harm than good. In a quintessential statement on the division of labor Smith states, "This division of labour, from which so many advantages are derived, is not originally the effect of any human wisdom" (Smith 1776, 25). More directly Smith remarks, "I have 
never known much good done by those who affected to trade for the public good" (Smith 1776, 456). Smith's summation of joint-stock companies ties in to this general theme found in $W N$, "The joint stock companies, which are established for the publick spirited purpose of promoting some particular manufacture... scarce ever fail to do more harm than good" (Smith 1776, 758). For Smith, joint-stock companies, in one way or another, are tied to privileges.

The political process is involved in joint-stock companies by allowing the sovereign the ability to pick and choose which companies could be founded. Because Smith never considers a free incorporation law whereby any company could form as a joint-stock company it is conceded that Smith tacitly supports the intervention in that manner. But, Smith's main concern with joint-stock companies is limiting the sovereign's scope. Smith wants to decrease the sovereign's desire to create joint-stock companies based on arguments of the public good. Smith feels that most joint-stock companies are often riddled with the same problems other government endeavors face as they often get privileged treatment ${ }^{5}$.

He limited his support of establishing joint stock organizations to four public works: banks, insurance, canals, and water-supply. Smith did not intend to start nationalizing numerous segments of the economy. Instead, Smith's discussion "relates exclusively to the duty of the sovereign to observe proper methods for screening jointstock or public company concessions" (West 1977, 11). Smith had three basic

\footnotetext{
${ }^{5}$ Much scholarship that supports an interventionist reading of Smith centers on Smith's criticism of jointstock companies and more specifically the East India Company. Anderson and Tollison argue that "In his analysis of the East India Company, Smith was not diagnosing market failure; he was diagnosing government failure" (Anderson and Tollison 1982, 1249).
} 
requirements for joint stock companies. First, the operation of the company had to be fairly routine or simple. Second, the establishment has to clearly provide for the general utility more than common trades. And finally, there were greater capital requirements than could generally be brought together by a small number of private investors.

The third and final requirement of assembling capital seems to carry the most weight in Smith's arguments (Anderson and Tollison 1982, 1244-1245; West 1977, 11). Nonetheless, Smith keeps all three as requirements to limit the public application of joint stock companies. He explains that the three requirements limit the scope and application for joint stock companies, "except the four trades mentioned above, I have not been able to recollect any other in which all the three circumstances, requisite for rendering reasonable the establishment of a joint stock company, concur" (Smith 1776, 758). Smith also notes that a list of fifty-five joint stock companies for foreign trade had been compiled by Abbé Morellet with the conclusion that all had failed due to mismanagement despite exclusive privileges (Smith 1776, 755). According to Smith there are few organizations that would be able to meet all the requirements and thus should properly be established. Smith's support of joint-stock company regulation is greatly limited in scope.

\section{Section 2, Part C: Mixed Support for the Intervention}

Although Smith's support of joint-stock companies constitutes the only rank five intervention, two interventions get a rank of four. The rank four interventions involve arguments by Smith that involve fuzzy, non-explicit, or mixed support of the intervention. Both mortgage registration and Smith's support of education fit this 
description. In Smith's arguments for mortgage registration and education, Smith is especially unclear in describing exactly what he is recommending or what his policy preferences are.

The claim that Smith's support of mortgage registration is waffling is probably not all that contentious. Smith's discussion of this particular contravention is very brief and it doesn't play a prominent role in most interpretations of Smith. Also, it is quite clear that Smith leaves the subject somewhat inconclusive. Although Smith admits, "The registration of mortgages... is extremely advantageous to the publick" (Smith 1776, 863), he is also very aware that a government run system of registration is problematic. He concludes, "Where the fees of registration have been made a source of revenue to the sovereign, register offices have commonly been multiplied without end, both for the deeds which ought to be registered, and for those which ought not" (Smith 1776, 863). He both argued for the intervention and warned against it without any decisive arguments as to which arguments he found more important. Smith was not very clear about what he recommended or how to devise a system that avoided all of the problems he brought up. So, while it is accepted that Smith supported mortgage registration, it is should also be acknowledged that his support was equivocal.

The other rank four intervention, support of public education, plays a more prominent role for interpretations of Smith. It is likely to be seen as more controversial. Because of the importance attached to Smith's take on education it will be dealt with in detail in a latter section. A short and simple rationale for classifying education as a rank four intervention could point solely to the end of Smith's section on education where he 
states that the system might have some advantages if it is handled entirely by private means (Smith 1776, 815). Although only one statement, Smith's conclusion epitomizes his lack of clear support for public involvement in education.

\section{Section 2, Part D: Interventions Without Much Support or Objection}

The rank three interventions are so ranked because Smith omits an objection to an intervention. The two interventions that fit this description are Smith's take on preventing a harmful disease such as leprosy and the establishment of a public post office. Both contraventions of natural liberty are really presented as minor side notes within WN and it's not entirely clear what Smith would recommend if he dealt with the subjects in more depth.

Smith brings up the prevention of leprosy within a tangent that is broken off from a discussion on education. The tie into leprosy comes from Smith's overview of how the ancient institutions of Greece and Rome maintained the martial spirit. Within his overview of the ancient institutions Smith states that, "Even though the martial spirit of the people were of no use towards the defence of the society... [it] would still deserve the most serious attention of government" (Smith 1776, 787). Smith is commenting on the ancient system, showing that in that system they would still give attention to the martial spirit even if it was of no use towards defense. He then comments that in the same manner "it would deserve its most serious attention to prevent a leprosy or any other loathsome and offensive disease" (Smith 1776, 787-788). Smith is still discussing the ancient system. 
In the next paragraph, Smith brings the discussion to his time. He argues that even if the "state was to derive no advantage from the instruction of the inferior ranks of people, it would still deserve its attention that they should not be altogether uninstructed" (Smith 1776, 788). Smith's focus is his current time and the instruction of people. Although he omits any objection to the public prevention of diseases such as leprosy he isn't actually making an argument for it or supporting an implementation of the ancient system in modern times.

Just before the leprosy example in $W N$, Smith provides an example where the Greek and Roman republics forced the whole body of people to learn military and gymnastic exercises. Just as in Smith's discussion on leprosy, he is highlighting the ancient system's approach to maintaining a martial spirit. It seems out of place to have the prevention of leprosy as an intervention that Smith supported while leaving out the imposition of learning military and gymnastic exercises. Smith covers them in the same manner. He explores what an ancient system did to cure a problem and does not come out against it. Neither forcing military exercises nor the prevention of leprosy come across as interventions that Smith is really trying to argue for or support. He is highlighting these two areas as practices of ancient systems to show their focus on needing to maintain the martial spirit. In the spirit of covering all the interventions Viner utilizes, the prevention of leprosy will be accepted as an intervention Smith supported. However, Smith did not support the contravention any more than merely refraining from objecting to it. 
The support of a public post office also fits within the rank three intervention where Smith omits an objection to the policy. Smith does not really suggest that he would support a public post office, though his brief comments show a mild approval that has led scholars to count this is one of Smith's interventionist statements. E.G. West summarizes Smith's acquiescence toward the subject as "in the instance of... the post office the world was set in its ways" (West 1977, 15). Smith never propounded the idea of the public provision of a post office.

Smith makes two brief statements about public post offices in $W N$. In the first reference Smith states that in almost all countries the post office makes a considerable revenue (Smith 1776, 724). Smith seems unopposed to running a post office via public means because it creates a revenue for the sovereign.

Smith's second reference to the post office echo's his first reference that mentions the revenue created. The second reference comes in Chapter II of book V on the sources of public revenue. Smith highlights the possibility of "the funds or sources of revenue which may peculiarly belong to the sovereign or commonwealth must consist, either in stock, or in land" (Smith 1776, 817). Stock and land are put forth as two potential sources of public revenue. For the rest of the first part of Chapter II, Smith discusses the appropriateness of creating public revenue through stock and land.

Smith's arguments are against the employment of stock to gain public revenue. Though, Smith admits, "small republicks have sometimes derived a considerable revenue from the profit of mercantile projects" (Smith 1776, 817). Within his concession Smith admits that the post office is "perhaps the only mercantile project which has been 
successfully managed by, I believe, every sort of government" (Smith 1776, 818). But, Smith does not go on to expound upon the benefits of a public post office. Instead, his point is geared more toward the idea that there are very few applications of stock or business ventures that can possibly be run without the likelihood of a net loss by a government. In the paragraph following Smith's statement that governments have run post offices successfully he becomes more pointed, "princes, however, have frequently engaged in many other mercantile projects... [and] they have scarce ever succeeded" (Smith 1776, 818). Smith also mentions that "no two characters seem more inconsistent than those of trader and sovereign" (Smith 1776, 819). For Smith, general revenue should not be sought out of mercantile projects.

After concluding that the mercantile projects are not a great source of revenue Smith suggests lending at interest and then concludes against that approach as well. Smith states,

The unstable and perishable nature of stock and credit, however, render them unfit to be trusted to, as the principal funds of that sure, steady permanent revenue, which can alone give security and dignity to government. The government of no great nation, that was advanced beyond the shepherd state, seems ever to have derived the greater part of its publick revenue from such sources. (Smith 1776, 820-821)

Again, Smith's main point is showing an opposition to these sources of government revenue.

Smith concludes part I by discussing land as a source of revenue for the public. Smith's pattern is the same. He discussed the employment of stock in mercantile projects and concluded that it was not a very proper source of revenue. He discussed the lending of stock and concluded that it was not a very proper source of revenue. Finally, he 
introduces the employment of land and once again concludes that it is not a great source of revenue. The section, it seems, is more of a negation of achieving revenue in such a way than a support of any of the projects including the public post office. Smith concludes the section,

public stock and publick lands, therefore, the two sources of revenue which may peculiarly belong to the sovereign or commonwealth, being both improper and insufficient funds for defraying the necessary expence of any great and civilized state; it remains that this expence must, the greater part of it, be defrayed by taxes (Smith 1776, 824).

Smith's part I to the section sets up his part II, Of Taxes.

Adam Smith's supposed support of the public post office is little more than the omission of any direct arguments against the practice. Smith was using the current practice to prove a point that very few mercantile projects of its type can even provide any revenue. He may have been willing to accept the public provision of post offices despite holding a private belief against it. It is also possible he favored public post offices, but there is not strong support for, nor attacks against, such a policy in $W N$. In WN Smith recognizes that public post offices currently run at a net benefit to the sovereign, but his discussion of post offices ends there. His main point is that very few if any other projects can create revenue in this manner and similar projects should be avoided. It seems more proper to label his support of public post offices as a mere omission of any argument against them, rather than suggesting that he put forth support for the intervention.

\section{Section 2, Part E: Support with Concerns}


The rank two interventions are so ranked because they are brought up with some favorable remarks, but Smith has serious reservations about the intervention. Although Smith casts some form of doubt over a number of his interventionist suggestions, in these cases Smith shows serious flaws with the intervention. The general tone of Smith's suggestion is one of great hesitation. One intervention, the Navigation Acts, clearly fits this description.

The Navigation Acts required that certain enumerated commodities of the British colonies remain confined to the market of the mother country (Smith 1776, 577). The theory is that Britain benefits from the monopoly trade of the enumerated commodities. In theory, the Navigation Acts would create benefits by economic means, but they also promised to help provide a military advantage. The Navigation Acts would bolster Britain's navy by augmenting the demand for ships to sail the Atlantic on their voyage to colonies. With more ships built and more men trained at sea the naval prowess of Britain was surely to grow.

Smith does give favor to the intent of the Navigation Acts, but he also attacks them. The strength of Smith's support involves his statement that there are two cases which it will "generally be advantageous to lay some burden upon foreign, for the encouragement of the domestick industry" (Smith 1776, 463). Smith's first case is when some particular industry is needed for the public defense. He then mentions the intent of the Navigation Acts to increase the number of sailors and notes the proper motive of the act. Smith famously goes on to call the Act of Navigation "perhaps, the wisest of all 
commercial regulations of England" (Smith 1776, 465). Given these comments, Smith's support of the Navigation Act's seems relatively clear cut.

When one reads Smith's collection of comments on the Navigation Acts the clear picture of favoring the legislation starts to fade. Time and time again Smith attacks the economic argument that the Navigation Acts create an economic advantage. Smith summarizes his economic feelings on the matter in the same section he suggests the naval advantage, "The act of navigation is not favourable to foreign commerce, or to the growth of that opulence which can arise from it" (Smith 1776, 464). In another, more detailed section, Smith again denies the potential economic advantage from the Navigation Acts,

whatever raises in any country the ordinary rate of profit higher than it otherwise would be, necessarily subjects that country both to an absolute and to a relative disadvantage in every branch of trade of which she has not the monopoly (Smith 1776, 599).

Soon after these statements Smith warns about the possibly severe consequences of propping up particular markets within an economy. Smith depreciates the possible economic advantage of the Navigation Acts.

Smith also draws serious questions about the military advantages of the Navigation Acts. Smith claims that the British Navy was great during the Dutch war, but notes that "this great naval power could not, in either of those wars, be owing to the act of navigation" (Smith 1776, 597). The trade which really helped generate Britain's great naval power was the trade with Europe and not with the colonies. The gain from trade with the colonies could exist, but Smith points out the reality that with free trade the colonies would have flourished more quickly and a good deal of the trade still would 
have been with Britain. Any assumption that the monopoly trade of some goods caused the great naval advantage of Britain is downplayed by Smith.

Smith's take on the Navigation Acts is reserved. His support of the Navigation Acts is often listed in Smith's support of public policies, yet Smith himself raises questions about the two possible advantages of the Acts. In addition, Smith's conclusion on the matter is not supportive. He worries about the potential disorder caused by propping up some markets within an economy over others,

Some moderate and gradual relaxation of the laws which give to Great Britain the exlusive trade to the colonies, till it is rendered in a great measure free, seems to be the only expedient which can, in all future times, deliver her from this danger (Smtih 1776, 606).

The only real debate for Smith is how the legislature is going to journey towards a more perfect liberty. The support for the Navigation Acts exists in $W N$, but it is not without very serious objections and reservations against the Acts.

\section{Section 2, Part F: Explicit Concessions to an Intervention}

The rank one intervention is argued against in principle, but accepted as a concession. Smith states that he is willing to accept the intervention because his first best solution is not a viable option given the current political and social climate. The only intervention that is placed as rank one intervention is done so because Smith makes it explicitly clear that his support is a concession to the bias against his more free market ideas.

The rank one intervention is Smith's take on corn bounties. Smith had a number of reasons for disliking the bounties and restrictions on corn trade. He begins his 
digression on the corn bounties as follows, "I cannot conclude this chapter concerning bounties, without observing that the praises which have been bestowed upon the law which establishes the bounty upon the exportation of corn, and upon that system of regulations which is connected with it, are altogether unmerited" (Smith 1776, 524). Thus, Smith started his discussion on bounties with a harsh and unequivocal stance that the praises given to bounty laws are completely incorrect. Further, Smith goes on to examine four reasons why the restrictions are as contemptible as he claims. First, he explains how the price mechanism helps encourage efficient use of the corn. Second, he explains that limiting trade reduces real wealth. Third, he shows that restricting trade increases the potential for a drastic market shortage because all surpluses are avoided. And finally, Smith shows how the restrictions prevent all of Great Britain from being a storehouse or middleman for corn trade and thus lose all associated advantages.

After explaining his four reasons why the restrictions are undesirable, Smith provides his policy prescription, "If bounties are as improper as I have endeavoured to prove them to be, the sooner they cease, and the lower they are, so much the better" (Smith 1776, 542). But then, at the very end of the section, Smith turns his attention to a recent change in the corn laws. Smith states that the new system is "in many respects better than the ancient one, but in one or two respects perhaps not quite so good" (Smith 1776, 541). After spending an entire section denouncing the current bounty system found in Great Britain, Smith acknowledges the recent change as having some merit, but he still finds serious flaws with the law. 
At the very end of his discussion on corn bounties, the Solonesque Smith shines through. He finishes the entire section by stating, "With all its imperfections, however, we may perhaps say of it what was said of the laws of Solon, that, though not the best in itself, it is the best which the interests, prejudices, and temper of the times would admit of" (Smith 1776, 543) ${ }^{6}$. Smith says we must acknowledge some of the prejudices of others and compromise accordingly, deviating from the best possible policy towards one that is at least liberalizing in relation to the erstwhile status quo. Having already written his harsh section on bounties Smith was not going to take back his statements about the ideal policy in this case, but he was willing to endorse recent changes. Smith accepts the intervention, but he does so explicitly as a concession after he argues against it in principle.

\section{Section 2, Part G: Conclusion to Section 2}

The interpretation of Smith as an unambiguous supporter of all eighteen interventions catalogued above should be questioned. In commentary on Smith's writing, it seems to be a right of passage for academic authors to point out the cracks in the interpretation of Smith as a straightforward free market thinker. However, the overwhelming tendency to point out Smith's breeches with natural liberty has led to a somewhat tacit acceptance that Smith whole heartedly desired the interventions he addressed. There has been an overcorrection in the literature. Even the simplified

\footnotetext{
${ }^{6}$ It should also be noted that this sentence was not in the first addition of the Wealth of Nations, but was added most likely in the second edition most likely after meeting with Burke who pushed the new bill through the House of Commons (Viner 1965, 26-27). The second edition of the Wealth of Nations was published in 1778 .
} 
general rankings covered thus far start to show a level of error with such an interpretation of Smith. The cataloguing above was fairly generous to recent scholarship and many of the supposed explicit interventions could be argued to be soft or hesitant. In addition, an examination of all of the explicitly supported interventions leaves mostly tenuous interventions.

The overcorrection in the literature on Smith gravitates toward pointing out the potential ramifications of extending Smith's interventionist statements into a possible justification of something like a modern mixed economy, but that literature is missing Smith's Solonesque style. The basic ranking and overview of his concessions shows a few minimal cracks in the overly interventionist interpretation of Smith. The moderate level of support, periods of waffling, and even blatant objections to his own interventionist recommendations make one start to wonder if Adam Smith left a little wiggle room for pacifying the public bias in $W N$. The rest of the paper will examine the other ways in which we can see Smith's Solonesque approach. In the end, the minimal cracks will prove to be much larger gaping holes in the interventionist interpretation of Smith.

\section{Section 3: All Interventions Are Not Equal}

For a proponent of liberty, different types of interventions carry different weights. Some interventions are supported for reasons that stand in complete opposition to the 
foundational aspects of liberty, but other interventions merely tread over the fringes of pro-liberty ideals. Interventions will vary with symbolic meaning, future ramifications for policy, actual scope of coercion, and so on. With different kinds of exceptions to liberty, you end up with a different character or flavor of intervention. In short, for a proponent of liberty, all interventions are not equal.

In many of Smith's more interventionist moments in $W N$, the character of his discussion is not in stark contrast to his pro-liberty roots $^{7}$. One should view differently Smith's claims if they are attacks on the core of a liberty movement versus attacks on the fringes of the liberty movement. When Smith supports an intervention that is of mild importance to the liberty movement, or if he does so with reasoning that keeps him in line with his liberty principles, the support should be understood as a sort of discounted intervention.

Much of Smith's interventionism is of a drastically different dynamic than modern interventionism. Smith is a classical liberal and he is no exception to their tradition of taking a pragmatic approach. When one deviates from liberty with a practical concern for maintaining liberty in the long run, it is far different from deviating for other reasons such as public goods arguments or welfare-state reasons.

One can imagine sitting in front of a computer selecting which policies a country will enact. When looking at the dynamic of an intervention it is not just a question of, Do you press the interventionist button or the liberty button? It matters why you push the

\footnotetext{
${ }^{7}$ For one primary example see Section 4 Part A of this paper for Smith's take on Education. Often Smith's take on education is shown to be one of his primary interventions and yet Smith's support of the intervention emphasizes a system where the majority of the payments to teachers made by consumers - A very liberty friendly approach.
} 
button as well. There are two ways in which Smith's push of the interventionist button should be understood as discounted. The first involves Smith's continual concern for liberty at large despite making the claim for some immediate or small scale coercion. The second form in which Smith's interventions should be discounted comes from the type of violation of liberty. In a few instances Smith's support for intervention is much more closely aligned with a clarification of property rights than what most would consider an interventionist bent. If one views these weak interventionist stances as on par with more stringently interventionist approaches Smith's legacy and the understanding of his approach can become greatly distorted.

\section{Section 3, Part A: Direct and Overall Liberty}

The first form of my call to weaken our view of Smith's interventionism involves the distinction between direct and overall liberty in analyzing public policies. Direct liberty corresponds to the inherent aspects of a policy reform, while overall liberty subsumes also its wider and long-run aspects (Klein and Clark 2010). For example, laws that forbid the ownership or exchange of certain forms of weaponry are clearly coercive, in the direct sense. But such restrictions may be pluses for overall liberty, as they may disarm or defuse private coercion.

In most instances direct and overall liberty will align. At times direct and overall liberty will not align. When direct and overall do not align the generic use of the word liberty will commonly be direct liberty. Such is the case when examining the claims about Adam Smith's support of interventions. If an author suggests that Smith supported 
a policy that broke with his system of natural liberty, the author is suggesting that Smith has supported a breach of direct liberty. But, it seems evident that when you deviate from directly liberty with overall liberty arguments it is seemingly less of a violation of the spirit of liberty. When the reasons given are overall liberty, there is affirmation of a wider or larger liberty principle. Thus, when direct liberty and overall liberty do not align there is a considerable grey area in which the proponent of liberty should not be seen as a strong interventionist.

Although Smith doesn't use the terms direct and overall liberty, he applies something very close to the concepts. Throughout his work Smith is concerned with violations of natural liberty, but from time to time he notes the ambiguity that can arise when following the liberty principle. The tone in which Smith puts forth support for a number of interventions is very much in line with the direct and overall liberty concept. For example, Smith states, "those exertions of the natural liberty of a few individuals, which might endanger the security of the whole society, are, and ought to be, restrained by the laws of all governments" (Smith 1776, 324). For Smith, direct violations of liberty can be desirable if they help protect liberty on some larger overall scale. Smith's approach tacitly acknowledges the potential ambiguity between direct and overall liberty and he occasionally highlights a distinction that roughly fits that between direct and overall liberty.

To clarify the distinction between direct and overall liberty one can collapse the scope and time aspects into a single dimension. Think of a spectrum of "directness," ranging from the most direct features of the action (and concomitant enforcement) on to 
indirect effects of varying range. Figure 1 represents this "directness" range of features and effects. The left endpoint considers the facets more or less inherent in the reform itself. In this aspect requiring houses to have a "party wall" (or firewall) is clearly a reduction of liberty. At the other end is the overall aspect of the reform. Overall liberty is the union or sum of the indirect effects and the direct features. It would include everything that arguably might come in the train of the reform.

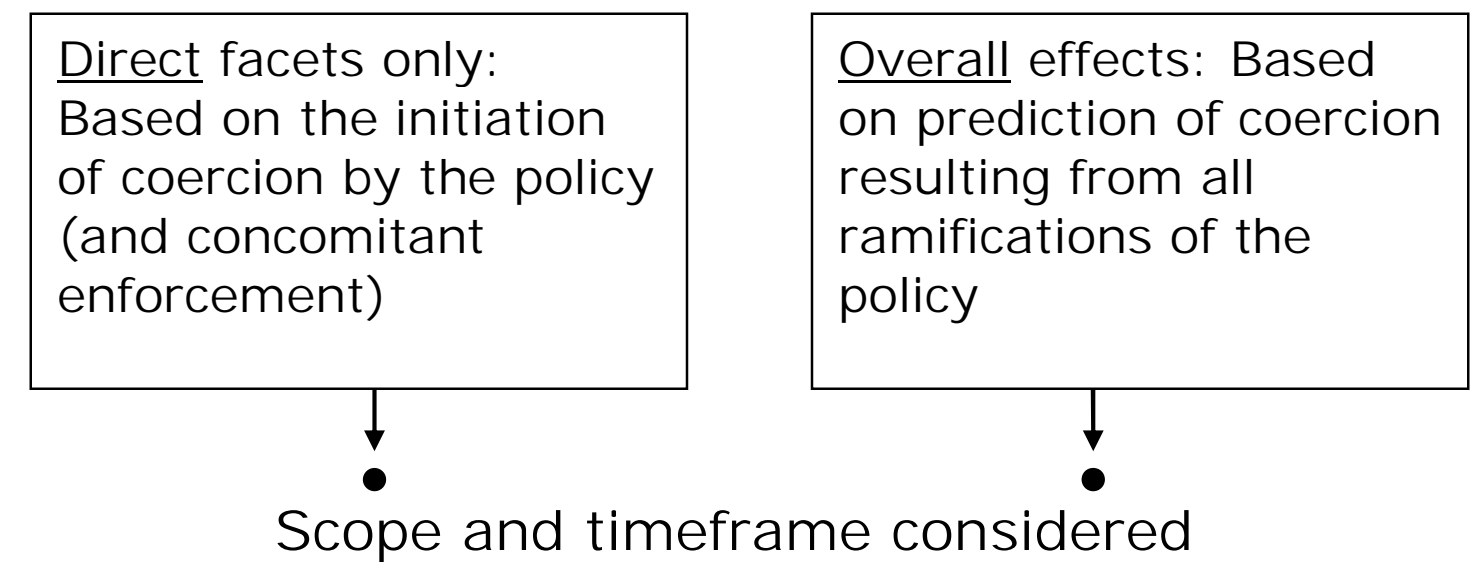

Figure 1: The Range of a Reform's Aspect of Liberty

For a proponent of liberty, the potential for conflict between direct and overall liberty creates a more complex line of argumentation. Nonetheless, the interplay of society and politics is complex and the disagreement between direct and overall may occur $^{8}$. While, not using the exact terms direct and overall liberty, Smith accepted the idea that pro-liberty policies could have effects that reduce overall liberty. In addition he accepted the idea that interventions could have effects that augment overall liberty. In

\footnotetext{
${ }^{8}$ There are a number of reasons why direct and overall often will be aligned with each other. For more see Klein and Clark (2010).
} 
Smith's work there are a number of policy issues that have a loose fit to direct and overall liberty issues.

\section{Section 3, Part B: Small Denomination Notes, Party Walls, and Liberty}

Smith states something very similar to a concern for the ambiguity between direct and overall liberty in his digression on small denomination notes. Smith's concern and support for a limit on small denomination notes was a result of the many bankruptcies going on in the country banks of England. Smith was not alone; the popular unrest with the bankruptcies was directed toward the circulation of the small denomination promissory notes. Smith seems to worry that the current banking practices in England created a situation where "beggarly banks" can cause "a very great calamity" for the poor, by not honoring the small-denomination notes, thus arguably violating a contract and hence violating liberty.

There is a loose fit between Smith's take on the small denomination note restrictions and the direct and overall liberty concepts. Smith's arguments are close to a statement that a restriction on the notes would be a violation of direct liberty, but he points out that the gain to overall liberty could outweigh the harm from the violation of direct liberty. Smith claims that the restriction on notes may be called a "manifest violation" of natural liberty. Right after suggesting that the restrictions are a manifest violation of natural liberty, Smith switches his tone and states that the regulations, "may, no doubt, be considered in some respect a violation of natural liberty" (Smith 1776, 324). Smith's statement that in some respects the restrictions must be considered a violation of 
liberty suggest that in some other respect the restriction supports liberty. Smith clarifies what he means by showing how a restriction could aid the security of the entire society. Smith states, "But those exertions of the natural liberty of a few individuals, which might endanger the security of the whole society, are, and ought to be, restrained by the laws of all governments" (Smith 1776, 324). Smith's prediction is that although the direct aspects of the policy violate natural liberty, their overall ramifications help protect and secure the level of liberty in general. Overall, the loose tie to the direct and overall liberty concepts is an example of how Smith has an adherence to a more general liberty principle despite showing support for an intervention.

When considering how Smith's support of interventions parallels direct and overall liberty rationales, it should be pointed out Smith uses the word security, and not liberty. There is a slight difference that admittedly detracts from the parallel, nonetheless the tie remains.

One difference between liberty and security relates to intentions. For liberty, intention does matter to some extent, whereas when one is concerned with security intentions are more secondary. Suppose that lightening strikes your house and causes a fire. Your lack of a party wall allows the fire to spread to your neighbor's house. Did you coerce your neighbor? Did you transgress his property, and hence his liberty? Under most conceptions of liberty the lack of a party wall would not be coercion. However, the neighbor's security is missing. For liberty the intention matters, but for one's security there is not a consideration of intention only safety. If you deliberately set fire to your neighbor's house, you would certainly be violating his liberty; and if you set fire to your 
own house when there clearly is some risk of it spreading to your neighbor's, again you violate your neighbor's liberty in that event.

When Smith worries about the very great calamity caused by small denomination notes, the problem is a type of coercion by individuals. There is intention by the beggarly banks creating the small denomination notes. It is a type of fraud that is, at least in Smith's opinion, being prevented by the government coercion of legally restricting the denomination of notes. One might say that a direct liberty is being violated in order to advance overall liberty.

It is not clear that the party walls regulation is preventing coercion by coercion because of the lack of coercion when intention is not present. The direct and overall liberty parallel is thus not necessarily as clear as it may seem in this example that Smith gives. Smith does make clear that the government coercion is of the same type. But in the end, the language Smith uses is that it is a break with liberty to get security and not to get some larger measure of liberty. There is a subtle difference, but nonetheless the parallel remains. In the case of small denomination notes and party walls, as in others, Smith makes arguments that may be interpreted as showing sensitivity to possible disagreements between direct and overall liberty.

\section{Section 3, Part C: Other Cases Where Direct and Overall Liberty May Apply}

Adam Smith has other passages that are moderately related to the issues of direct and overall liberty. Smith's potential support for standing armies and some public assistance with education are both tied to avoiding fanaticism and upheaval of the general 
public (Smith 1776, 697-698, 786-788). Although there may be other advantages, Smith is willing to consider such policies in order to try to avoid "dreadful disorders" and "unnecessary opposition to the measures of government" (Smith 1776, 788). Smith lends his brief support to the requirement of party walls with arguments akin to direct and overall liberty concepts. Overall, there are a number of cases in which Smith uses the same tone as the direct and overall liberty distinction during his consideration of possible interventions.

There are two cases in which it is well accepted that Smith has an interventionist take and yet Smith's potential support of intervention is based solely on the defense of the nation's liberty. In these two cases Smith supports a direct violation of liberty on grounds of national defense. The first is his support of bounties on strategic military goods.

If any particular manufacture was necessary, indeed, for the defence of the society, it might not always be prudent to depend upon our neighboours for the supply; and if such manufacture could not otherways be supported at home, it might not be unreasonable that all the other branches of industry should be taxed in order to support it. The bounties upon the exportation of British-made sail-cloth, and British-made gun-powder, may, perhaps, both be vindicated upon this principle (Smith 1776, 522$523)$.

Smith's support is related to the direct and overall concept. The violations created by the bounties are trumped by the violations that would occur without them as the entire country may be ransacked. Although Smith hedges his statement by stating that it "may, perhaps" vindicate the use of coercive measures, it is still an example that shows Smith's direct and overall liberty understanding. 
In addition, the passage above, although fairly straight forward, is surrounded by doubt. The paragraphs before this passage on strategic bounties go through the government failures of fishery bounties and the paragraph following the passage Smith mentions the potential misuse of the strategic bounty argument. The brief section is a bit muffled and hedged in support of the interventions with a number of strong concerns creating the bulk of the material Smith covers throughout the rest of the section.

Although Smith's hedging slightly weakens the case that he was willing to use something similar to direct and overall liberty concepts, the hedging should also prevent us from suggesting that Smith strongly supported these coercive measures in the first place. Either way, the paragraphs fit with the evidence from the rest of the paper. Either Smith didn't feel that strongly about his support of strategic material intervention or his support was predicated on a concern for liberty.

The second case in which Smith supports a direct violation of liberty on grounds of defense is his support of the Navigation Acts.

The defence of Great Britain, for example, depends very much upon the number of its sailors and shipping... The act of navigation is not favourable to foreign commerce, or to the growth of that opulence which can arise from it... As defence, however, is of much more importance than opulence, the act of navigation is, perhaps the wisest of all the commercial regulations of England (Smith 1776, 463-465).

Once again Smith raises some doubts as to how much he really supports the Navigation Acts by chipping away at his own arguments. But, even if one understands Smith to be in support of the intervention, the arguments are based around the idea that in some situations we may need to consider giving up some direct notion of liberty to help ensure 
overall liberty. The defense of the nation, protecting the lives and liberties of its people, is Smith's reason for any support of intervention in the shipping industry.

\section{Section 3, Part D: Interventions or Property Rights Clarification}

Thus, some of Smith's support of intervention can be seen as quite related to the occasional tensions between direct and overall liberty. Yet other of Smith's interventions remain closely related to a liberty principle because they might be better understood as clarifications of property rights than as interventions. When Smith discusses his opposition to payment-in-kind and joint stock organizations there is room for debate that Smith is more focused on how property rights are enforced than intervening in the markets. In both cases, the connection to an interventionist inclination is weak.

The first area where it is somewhat troublesome to see Smith as definitively approving of a contravention of natural liberty is his opposition to payment-in-kind. Although Smith did explicitly support the restriction of making payments to workers with goods and not money, it's not clear that his statements should be seen as evidence of Smith's interventionist ideas. When looking at Smith's arguments, his concern is contract enforcement. Smith states, "It only obliges them to pay that value in money, which they pretended to pay, but did not always really pay, in goods" (Smith 1776, 158). Enforcing the actual contractual agreement is the goal. Although I admit that my understanding of the law, its enforcement, and the practices it relates to is only hazy, I think it is worth adding that, presumably, a law that banned payment-in-kind would simply go unenforced when parties private agree to payment-in-kind - since who then 
would complain of the in-kind payment? - in which case the restrictive part of the law would in practice not be binding.

In the surrounding section Smith does not hint at any other reason for the restriction against payment-in-kind, nor does he hint at any desire to regulate wages. In fact, the surrounding section is focused on the problems with trying to regulate payments and profits of merchants. Smith is supporting a law that makes sure the masters live up to their end of the contract and pay the workmen an agreed upon price - here we have the essence of contract enforcement and not interventionist regulation. The desire to control the choice of exchange media is clearly not Smith's focus. This type of intervention, if it is so labeled, is a minute concession to a system of natural liberty.

The second case where Smith's concern is more with adjusting the legal framework and resulting property rights is his discussion of joint stock companies. Although some of Smith's arguments stray slightly, the general concern remains with overcoming a lack of structured property rights in order to unleash the private sector. Under the regime present during Smith's day the ability to create larger-scale markets was nearly completely hampered by the legal framework. As E.G. West explains, "The key historical fact is that in Smith's time large groups of individuals were so hindered by the absence of an appropriate variety of legal instruments with limited liability that much needed capital markets were blocked" (West 1977, 6). Interventionist discretion provided the only path to carrying on larger-scale markets prior to Smith's writing of the $W N$. Smith wanted to make sure that joint-stock companies were not being used as another device to promote the political ends of certain factions. Smith's options were 
limited because more general statutes enforcing a framework of property rights simply did not exist during Smith's day.

Smith's concern for an enforcement of property rights in the cases of payment-inkind and joint stock companies align fairly well with Smith's pro-liberty vision and spirit. If one is to consider these cases interventions, the type of intervention Smith is proposing is modest. The delineation and enforcement of property rights stand at the heart of classical liberal notions of a free society. Smith's suggestions in both the payment-inkind and joint stock company sections place a great deal of importance on the delineation and enforcement of property and contractual rights, and thus should be considered weaker interventions.

\section{Section 3, Part E: Conclusion to Section 3}

This section has provided evidence that again weakens the interventionist interpretations of Smith. Smith takes interventionist stances that remain closely aligned with the cause of liberty in two ways. Smith's arguments often parallel the direct and overall liberty distinction in the cases of party walls, small denomination notes, the Navigation Acts, standing armies, education, and strategic military bounties. His arguments are centered on enforcement of property rights in the cases of payment-in-kind and joint stock companies. If one views these weak interventionist stances as on par with more stringently interventionist approaches Smith's legacy and the understanding of his approach can become greatly distorted. In this section, Smith's willingness to bend, but certainly not contradict the concept of liberty is highlighted. Like Solon, Smith admires 
some room for compromise and a softer adherence to a principle. These cases of weaker interventions are right in line with Smith's approach. Smith wouldn't be astounded at these concessions; it seems more likely that he would find his own approach and sentiments quite appropriate and good-natured.

\section{Section 4: The Level of the Argument}

The type of support Smith gives to his interventions is often liberty friendly. But, even when he supports an intervention without any connection to the liberty principle there is still room for his preference of Solonesque rhetoric to shine through. The next way to examine Smith's rhetoric in this regard is to look for instances when Smith hints that he may be acting practically and dealing with the particulars of an issue as opposed to revealing his personal ideal design for society. This approach allows Smith to placate those biased against him by choosing not to fight some battles that would only arouse great passions against him. It will be argued that the vast literature on Smith's inconsistencies points toward the probability that Smith did indeed pick and choose his battles wisely. Smith's inconsistencies, it will be argued, result in part from Smith choosing to avoid the arrogance of arguing for his foundational ideals for society in all possible cases.

Smith's occasional inconsistency in areas of $W N$ makes one feel as though he was of two minds. Jacob Viner claimed that Smith's approach “displayed a fine tolerance for a generous measure of inconsistency" (Viner 1927, 216). If we combine all of his works and try to generate one consistent worldview, even more contradictions seem to arise. 
One take on Smith's inconsistency is to simply downplay these occurrences as trivial. His tendency to waffle and his inconsistent remarks can be seen, as Viner seemed to suggest, as simply artifacts of his absent-minded personality or mere errors of the author.

Another take on Smith's inconsistency lies with his strategic approach. The tolerance for inconsistency, when used as a strategic tool to pacify radical emotions, could come to fruition as somewhat odd or muddled statements supporting the status quo or mainstream views. Because soothing radical emotions was so central to Smith (Clark 2011), analyzing his work for situations where he may have possibly bent his own beliefs a bit seems quite plausible. In fact, much can be gathered from the apparent inconsistencies with an understanding of Smith's attention to the prevailing prejudice that surrounded him.

\section{Section 4, Part A: Challenging and Bargaining}

Smith's views of natural liberty, mixed with his Solonesque approach, lead to moments of inconsistency and other moments of apparent, but not actual, inconsistency. The interplay between these two forces - being radical while rendering judgments with some respect for the bias of the populace - creates a tension in Smith's work that remains unresolved centuries after writing WN. Although the tension will remain unresolved, one productive way to understand where some of Smith's inconsistencies may arise from will be to distinguish between an approach of challenging and an approach of bargaining. The distinction between challenging and bargaining can be traced back to Shelby Steele's 
The Content of our Character ${ }^{9}$. The formulation of challenging and bargaining developed here will share a strong tie with Steele's formulation, but they are not necessarily identical concepts. Steele's distinction sets apart two ways in which individuals deal with racial differences, but it applies to the way in which people deal with political differences as well.

The dichotomy essentially helps differentiate how people deal with opposition and bias against their own strong beliefs. Steele says that, "a bargainer says, I already believe you are innocent (good, fair minded) and have faith that you will prove it. A challenger says, If you are innocent, then prove it" (Steele 1990,11). A bargainer is someone who will join or cooperate with those in power. They will stand with others as colleagues in power, but nonetheless as something slightly different from them. A challenger highlights the difference between the two opposing views and is willing to attack the ideas of others.

The distinction of challenging and bargaining helps us examine Adam Smith's public policy recommendations. Of upmost importance will be the difference between how challenging involves arguing against central issues whereas bargaining allows one to deal with the particulars of the circumstance. The difference can be seen in figure $2^{10}$. If an individual is to bargain, they may begin at position $\mathrm{S}$ and dispute others about holding belief Z. Challenging, on the other hand never deals with position S. Challenging is

\footnotetext{
${ }^{9}$ I'd like to acknowledge Dr. Daniel Klein for starting me down this path. In the distinction between bargaining and challenging I am merely following in his footsteps.

${ }^{10}$ Again, the diagram originates with ideas expressed by Dr. Daniel Klein.
} 
more drastic, there is a move directly to position $\mathrm{Q}$ and a dispute of belief $\mathrm{W}$. Challenging questions the foundational issue.

Figure 2: The Level of Argumentation

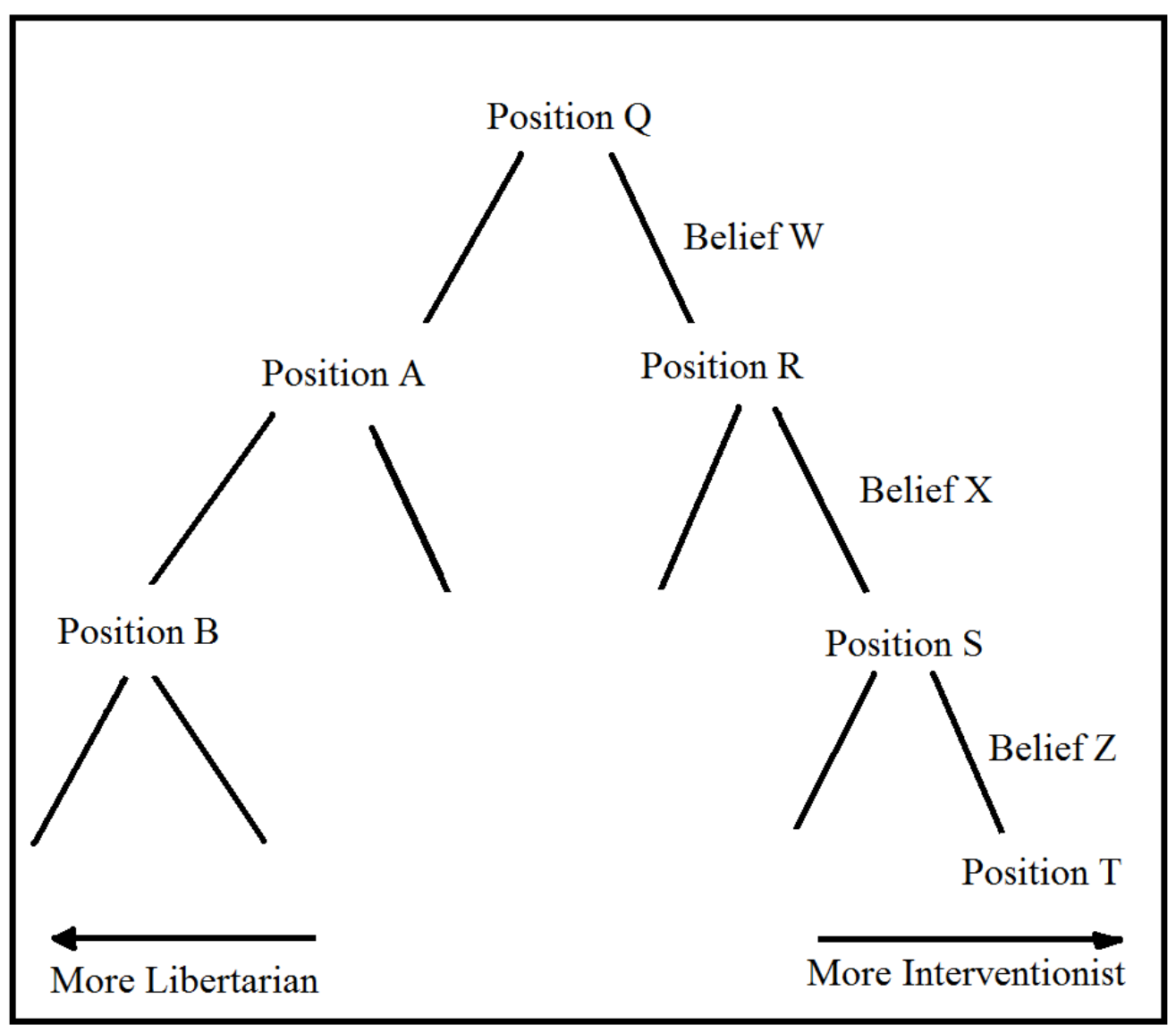

An example of the distinction could be a discussion about whether or not to liberalize certain banking regulations. If one attempts to challenge, they may never get into the argument about the regulations. Instead, challenging involves a move where one opts out of this conversation and instead argues that the government should be out of the business of money all together. Not only should banking regulations be banished, but 
free banking should be the system in place. On the other hand, if one wanted to bargain, there could be a discussion on the relative merits of certain liberalizations within the current banking regulatory system.

When an individual is bargaining, they participate in discussions within the right half of figure 2. Challenging, on the other hand, attacks the very idea of being on the right half of the diagram. By bargaining, one makes statements that show the other side to be in error, but the other side is not necessarily fundamentally flawed. In Shelby Steele's terms, bargaining allows the opposition a chance to claim their innocence. They can maintain a feeling of essential goodness about their work, views, and beliefs in question. Bargaining allows the opposition to maintain a positive perception about their views and actions, yet nonetheless tries to persuade these views in a certain direction.

The difference between challenging and bargaining is not simply a difference between privately held policy views. For instance, in our last example, both the individual who challenged and the individual who bargained could feel that the first best solution to the situation is free banking, however, they have taken different approaches to discourse. One can hold an extreme view and bargain, and likewise one can hold a fairly middle of the road view and challenge. The difference is the strategic or rhetorical approach taken in the situation, not the preference of the individuals involved.

Some of Adam Smith's inconsistencies may be instances of Smith pursuing a particular issue despite holding a different central belief. If Smith conceded that some of the status quo interventions were acceptable, it may have been a result of his desire to put forth a public face that was reasonable and respectful to the ideas of his era. In different 
areas of Smith's work his inconsistencies come across as though they are instances of such compromise. This is not a call for Smith to be deified or treated as though every word he wrote can be shown to be sagacious. However, an understanding of Smith's approach opens the door for some of Smith's moments of inconsistency to be thought of in terms of tackling particular issues instead of challenging central ones. In the areas of education, the provision of roads, bridges, and canals, small denomination notes, and usury an understanding of the interplay between Smith's radical views and his Solonesque approach helps explain the apparent inconsistencies.

\section{Section 4, Part B: Education Inconsistencies}

The first and most prominent section of Smith's public policy inconsistencies will be Smith's section on education. Smith's discussion on education reform is anything but definite. As James Stanfield describes it, "Adam Smith tackles the issue of education and gets into what can only be described as a bit of muddle" (Stanfield 2005). Smith makes recommendations and commentary but seems to waffle at times about what he is suggesting. Most of Smith's support of intervention is given with at least some rebuttal against it. The section on education is continually contrasting two alternative systems of education, the endowment system and the Scottish parochial approach. Throughout Smith seems to be writing between the lines and suggesting that an additional interpretation, one of allowing the market to remain free in education, may in fact be the best. One can easily read the section in its entirety and not be certain as to what kind of program Smith is advocating or if he is advocating any position at all. 
Smith does give a number of potential problems with the purely voluntary provision of education. Smith is concerned with the English trend to send young students off with tutors to foreign countries for educational travels. Smith had been a part of the practice himself; he started writing $W N$ on such a trip while tutoring the Duke of Buccleuch. Smith is worried that students tend to return from these trips with little gain and if anything are more conceited and unprincipled (Smith 1776, 773). Smith also makes the case that a free society, with a vast division of labor, will create some degeneracy within the public. Within a free society the specialization that naturally results will inevitably create a situation where a good number of individuals simply repeat a small number of tasks. Smith worries that, "the uniformity of his stationary life naturally corrupts the courage of his mind" (Smith 1776, 782). Without a guarantee that the public will attain at least the basics of education, Smith is concerned that individuals will not develop their martial spirit and their ignorance will threaten the order of society (Hollander 1979, 543; Smith 1776, 786-788) ${ }^{11}$. Although the purely voluntary provision of education has some benefits, Smith clearly does not state that it is without any potential faults.

Smith described the problems with market provision, but that does not necessarily mean he would support any government intervention. One can find a free market system cold, unfair, and flawed yet still support it as the lesser of two evils. However, as discussed earlier, Smith does end up making some potential recommendations based around the Scottish parochial schools (Muller 1993, 151). The parochial schools became

\footnotetext{
${ }^{11}$ Smith's Lectures on Jurisprudence extend this argument.
} 
established in Scotland early in the eighteenth century. The schools were funded partly by public expense and partly by user fees (Muller 1993, 151). Smith was trying to avoid the problems he saw in market education while finding a way to avoid the errors of public programs. Apparently, he felt the relatively successful Scottish system navigated between these two errors fairly successfully.

However, when reading to find Smith's support of the Scottish system, his argumentation comes across as ambiguous, shifty, and extremely minimalist at times. The first line of his section on education starts with a very anti-interventionist message, "the institutions for the education of the youth may, in the same manner, furnish a revenue sufficient for defraying their own expence" (Smith 1776, 758). Smith goes on to say that in those cases where the revenue is not sufficient the general revenue of the society is very rarely used to supplement it and generally it is handled by local revenue. Right off the bat Smith is stating that the education of the youth should not demand much from public resources and certainly very little should come from the nation's general revenue.

In fact the entire start of the section provides a scathing review of teaching under any type of endowment system. Here most of Smith's remarks seem pointed at the collegiate level, but still Smith's general theme is very anti-interventionist. Smith even matter-of-factly observes that "those parts of education, it is to be observed, for the teaching of which there are no publick institutions, are generally best taught" (Smith 1776, 764). Even when trying to acquire a special skill the logic still holds for Smith. Fencing and dancing schools were paid for out of the pocket of the consumer and worked 
fairly well. However, riding schools were so costly that they were often public institutions and the benefits of such schools were much less.

Smith's support of the Scottish parochial schools becomes muddled at times because of his clear remarks against some aspects of the intervention. Smith argues that if there were no public institutions for education, frivolous subjects would not be taught (Smith 1776, 781). He also argues that the endowment system has ruined not only public teaching but also private teaching (Smith 1776, 780). And, he argues that public education would cause complications for the sovereign in religious matters (Smith 1776, 797). In these cases Smith gives arguments for a free system of education.

In some of Smith's supportive statements for interventions in education one can read between the lines and discount some of what Smith is saying. For instance, although Smith supports the parochial approach of Scotland for the education of the youth (Smith 1776, 781-788), he does so to combat their potential loss of "intellectual, social, and martial virtues" (Smith 1776, 782) caused by the progress of the division of labor. His arguments for protecting the martial spirit of the people seem only necessary without a standing army. He concludes that the advancement of the martial spirit could help diminish the size of a standing army if a country were to have one, but in the present times without a well-disciplined standing army the martial spirit alone may fail to secure the country. Smith may truly desire to change the foundational view that there is a requirement for a standing army ${ }^{12}$, but he seems to be dealing with the issue as it is

\footnotetext{
${ }^{12}$ Smith (1776), see pages 698-708.
} 
presented. His arguments here are clearly stepping away from his foundational belief and accepting a bargainer's approach and dealing instead with the particulars.

The particular issue Smith is debating over is the use of a parochial system or the current endowment system of education. One can see the structure of his argument by looking at the often overlooked start of his section. At the start of article II Smith sets forth an overview of the section on education. Although Smith makes numerous tangential remarks to give an overview of the importance and happenings in education throughout history, Smith's approach is centered on answering the questions he sets forth at the start of the section ${ }^{13}$. After a brief introduction to the education section, Smith asks,

Have those publick endowments contributed in general to promote the end of their institutions? Have they contributed to encourage the diligence, and to improve the abilities of the teachers? Have they directed the course of education towards objects more useful, both to the individual and to the publick, than those to which it would naturally have gone of its own accord? It should not seem very difficult to give at least a probable answer to each of those questions (Smith 1776, 759).

Here we see that Smith explicitly started the section by stating that his analysis is on the endowment system. He even provides the questions that he is attempting to answer throughout the section.

After putting forth the questions, Smith gives his account of the "probable answer to each of those questions." He writes about how the endowment system has a negative impact on teachers (Smith 1776, 760-764), and how it has negatively altered the direction of education (Smith 1776, 764-774). Smith then gives a brief historical overview of

\footnotetext{
${ }^{13}$ The section is article II of the first chapter of book 5 in the Wealth of Nations.
} 
education and looks at how the public endowment system has contributed to education in general. Thus, Smith has in part answered the three questions he set forth in the beginning of the section. During the rest of the section Smith tries to create a more complete understanding of the overall role of the education system. Only here does Smith start putting forth some suggestions. His conclusion is that the endowment system has a negative effect on the education of the youth. He provides one path to reconcile the errors of the endowment system with the desire to educate the youth: His solution is to follow something similar to the Scottish parochial system while eschewing the endowment system.

Even when Smith finishes article II and moves into article III, which is focused on the training of clergy and other religious education, Smith shows his concern is with the problems created by a current endowment-like practice. Once again Smith starts the section as an attack on an endowment based system.

The teachers of the doctrine which contains this instruction, in the same manner as other teachers, may either depend altogether for their subsistence upon the voluntary contributions of their hearers; or they may derive it from some other fund to which the law of their country may entitle them; such as a landed estate, a tythe or land tax, an established salary or stipend. Their exertion, their zeal and industry, and likely to be much greater in the former situation than in the latter (Smith 1776, 788).

Smith reestablishes his focus against the endowment system even in religious training. Smith's complaint is primarily with the endowment system that is in place for education and religious training and not with the market provision of education and religious training in general. 
In addition, Smith's final conclusion on the matter is often overlooked. Smith moderates any credence he gave to his interventionist suggestions. Smith writes that he is, perhaps, not completely in favor of any intervention in education.

The expence of the institutions for education and religious instruction, is likewise, no doubt, beneficial to the whole society... This expence, however, might perhaps with equal propriety, and even with some advantage, be defrayed altogether by those who receive the immediate benefit of such education and instruction, or by the voluntary contribution of those who think they have occasion for either the one or the other (Smith 1776, 815).

Those are Smith's final, summary words on the subject. Smith ends his chapter by partially contradicting his recommendations for utilizing the interventions found in the Scottish parochial system. He certainly contradicts the conclusion that many scholars take away from the section - he contradicts the idea that he whole-heartedly supports some level of intervention in education.

These statements are strong and important words for understanding Smith's take on education. Although Smith does hedge his statement by using the phrase "perhaps", he nonetheless states that the recommendations he puts forth for education reform might be equaled by free market provision. In fact, Smith puts in his statement that the free market provision might even have some advantage. Despite his entire lengthy section of suggestions for reform and complaints about the potential problems of market education, Smith ends the chapter by saying perhaps its better if we allow the system to be voluntary.

Smith's seemingly inconsistent statement at the end of the chapter is a result of his approach. Smith was worried about some of the errors in the education system and 
for the most part he is making certain to counter them. Like his approach to free trade, where Smith works against the errors of a mercantilist system, Smith is worried about the errors he currently sees in the endowment system. This is consistent with Jacob Viner's observation that Smith's primary objective was getting rid of bad government actions everything else was “to a large degree secondary" (Viner 1927, 218). Smith's section on education has a seemingly contradictory statement to close because Smith was really concerned with countering the errors of the endowment system.

It is apparent that Smith's approach is once again in line with Solon: he countered a poor government policy and made arguments that the prejudice of the populace could bear. For the most part, Smith was considering two different options, the endowment system and something similar to the parochial system. His arguments are that the parochial system has more merit. Smith's approach is to provide a best remedy given the regulatory desires and prejudices of the populace while trying to ameliorate the completely harmful practices around him. The section on education does not provide all of Smith's thoughts on the provision of education. He shows that article II was not an all encompassing section by stating at the end that perhaps free education would be just as beneficial or even better. His conclusion suggests that if he was attempting to provide a comprehensive take on education he would have given somewhat equal attention to market provided education. Although he subtly covers free market education, he does not give it the attention demanded by the endowment and parochial systems.

The conclusion that Smith sees some government intervention in education as desirable is more muddled and ambiguous than is commonly assumed. Smith's moments 
of shifting between arguments and his inconsistency are a part of his argumentation. Smith is not trying to challenge for fundamental reform within education, instead he selects a bargainer's path. Just because Smith did not champion free-market education does not mean that this was not his privately held view. And just because he appeared to be bargaining and a bit inconsistent in his arguments it does not mean his privately held view was for a completely free education system. What is clear is that neglecting his final statement, dismissing his inconsistency without regard to his strategic approach, and disregarding his opening questions on the endowment system promotes an improper portrayal of Smith's analysis.

\section{Section 4, Part C: Canals, Roads, harbors, and Bridges Inconsistency}

Of much less controversy is Smith's take on canals, roads, harbors, and bridges. However, Smith's statements once again show some inconsistency. Jacob Viner found the section on roads and canals completely puzzling, "In discussing the propriety of particular projects, however, he completely ignores the criterion he had laid down at the beginning of his discussion, namely, the impossibility of their being conducted profitably as private enterprise" (Viner 1927, 226). Smith does show favor to public works that promote commerce in general, but his reasoning of why shows signs of inconsistency.

Smith argues that having private ownership can be very beneficial. His main example is the canal of Languedoc. The canal was a massive and grand project of the French King Louis XIV. Smith used the example to show the benefits of private ownership. 
When that great work was finished, the most likely method, it was found, of keeping it in constant repair was to make a present of the tolls to Riquet the engineer, who planned and conducted the work. Those tolls constitute at present a very large estate to the different branches of the family of that gentleman, who have, therefore, a great interest to keep the work in constant repair (Smith 1776, 726).

Smith's example of the canal of Languedoc aptly shows how individual incentives are properly guided with private ownership.

The paragraph immediately following his example Smith concludes that the maintenance of works like high roads should be under the management of trustees and commissioners for safety reasons. "The tolls for the maintenance of a high road, cannot with any safety be made the property of private persons" (Smith 1776, 726). The high roads are actually more dangerous than canals according to Smith because while a lack of maintenance will make a canal impassible, one may venture on to an unmaintained, and thus very unsafe, high road. Smith gives evidence in one paragraph that based on experience the very best way to keep a canal "in constant repair" is private ownership. Then, in the very next paragraph Smith highlights the necessity for constant repair in roads, but concludes that private ownership will not suffice.

Within the actual section on roads and canals, the clearest contention with private ownership is Smith's inconsistent short paragraph on the safety of high roads; a defense clearly based on "reasons that are somewhat obscure" (West, 1977, 12). One can easily look at his arguments and conclude that they are built upon "insufficient grounds" (Friedman 1975, 12). For Smith, the conclusion that the bridges should not have private ownership shows waffling argumentation and inconsistency. 
Smith's inconsistency is especially prominent when Smith opens the very next paragraph discussing the problems of using commissioners or trustees. Smith admits that there have been many cases where the management of tolls has been complained about and rightly so. Smith feels the system will work towards better results, but still has some imperfections that need to be worked through.

When Smith analyzes the private ownership of roads, bridges, canals and harbors the inconsistency is stark. Smith does make a pointed conclusion against private ownership based on safety reasons, but he makes many statements to the contrary. Smith concludes that in countries such as China and France the reports of bridges and canals are likely only the main works within the countries. The upkeep of the more minor bridges and canals simply go ignored (Smith 1776, 730). Smith also states another problem with the maintenance being run by commissioners, "[the collected tolls] might perhaps have been dissipated in ornamental and unnecessary expences, while the most essential parts of the work were allowed to go to ruin" (Smith 1776, 726). Smith raises yet another concern when he comments that "at many turnpikes, it has been said, the money levied is more than double what is necessary for executing, in the compleatest manner, the work which is often executed in a very slovenly manner, and sometimes not executed at all" (Smith 1776, 726). Is Smith inconsistent with his remarks on roads, bridges, canals and harbors? The answer is certainly yes. Smith's only real conclusion comes down against private ownership of roads, but otherwise he argues how a lack of private ownership tends toward great neglect and deterioration. 
Smith's inconsistency, however, is once again partially a result of his approach. Smith's statements are in line with his idea that most of the time natural liberty will work perfectly fine. For one, he joins the side of those under the current regime by showing how his system fits within some of the current practices. He grants to those who are opposed to most of his foundational statements that he is on their side. However, Smith's partially inconsistent statements - a conclusion that states how the maintenance of good roads and canals can occur without private ownership despite having numerous arguments against it - show that Smith may be a soft supporter of such intervention. $\mathrm{He}$ is wavering and waffling in his support of these government public works.

It must be remembered that Adam Smith believes in putting forth the best system possible while trying to avoid the temptation to feel infallible in worldviews and ideas. It would make sense, then, that Smith wanted to avoid making his liberty principle the resounding standard by which we judge policy. Instead, Smith shows a concession to a theoretical liberty only stance. He claims that if public works will facilitate and help grow the commerce of the country then by all means they should be undertaken. The entire section on public works, and for that matter education, are Smith's concessions that if something is clearly to the "highest degree advantageous to a great society" (Smith $1776,723)$ then no matter if it involves interventions it should be done. Smith is letting his audience know that obtaining perfect liberty is not the goal. Smith's goal is the same as most everyone else -- creating a wealthy nation.

Adam Smith may very well have believed in the interventions he suggested in his section on roads, bridges, canals, and harbors. But, it is worth noting that his 
inconsistency shows signs that for Smith the actual policies may not have been as important as other issues. In this case, he not only wanted to show that the aid of commerce in general superseded his desire for liberty, he also argued harshly that the less local the administration of public works the more problematic they become. For Smith, this seems to be the foundational issue of the section.

Smith continually points to the incentives of private ownership and residual claimancy as the only real solutions for the problems of maintaining the public works; in doing so, his arguments point toward a more local administration. As Smith notes, the problems with a more local administration are "more easily corrected" (Smith 1776, 731) than those run nationally. Smith ends his section with a very harsh conclusion to the section. He understands the problems with local administration, but points out that the problems with larger scale administration are much greater. Smith gives the example of the fairly well working administration in Great Britain of turnpike trusts and then scathes the French for their more national administration, "In France... the application is not always more judicious, and the exaction is frequently the most cruel and oppressive" (Smith 1776, 731). Although the section may contain more content in favor of the public provision of roads, bridges, canals, and harbors, another major theme Smith seems to be concerned with is in line with his foundational beliefs against large scale intervention. His approach is palatable to the layman, it grants innocence to those who are a part of the current system of administration, and yet it still gets some points about Smith's foundational beliefs across. Adam Smith's take on roads, bridges, canals, and harbors has moments of inconsistency that are a result of his Solonesque approach. 


\section{Section 4, Part D: Small Denomination Notes and the Level of the Argument}

Smith's discussion on small denomination notes does not add an additional type

of intervention to the Scottish system, but Smith concedes some extension to the level of the regulation in order to deal with other areas of Britain. Smith's take on small denomination notes is an area where Smith lends some endorsement to an intervention but his approach indicates that it is important to examine the level of the argument. Smith's approach shows signs of acting practically and dealing with the particulars of an issue as opposed to revealing his personal ideal design for society.

In the bulk of the section on small denomination notes Smith provides reasons why one should be critical of government involvement of banking. Smith sets his regulatory limit at nothing beyond the regulation of small denomination notes and the restriction of the options clause - essentially Smith supports the Scottish status quo. According to Smith, Scotland in 1776 is getting banking right. In addition, Smith puts forth his arguments for an increase in the minimum amount of denomination of notes as an attack on the country banks of England - not the Scots. In total, Smith seems to be compromising by trying to meet the popular sentiment for stopping the problems of the country banks while still making a suggestion that allows notes of a lower denomination than used by the Bank of England. He holds the Scottish system as exemplar, yet he grants some concessions to try to make the system work throughout the kingdom of Great Britain.

When Scotland and England were formed into one kingdom by the union of 1707 their banking regulation remained separate. The Bank of Scotland was founded by an act 
of Scottish Parliament in 1695, but had no official ties or responsibilities to uphold for the government. After the union, the free competition of Scottish banks emerged in part because of the new, mainly English, rule over the land. The British Parliament, although regulating entry and competition against the Bank of England, did not act on any of the petitions to stop additional banks from starting up in Scotland (White 1984, 25). Scotland had a free competition of banking with few restrictions or regulations until about 1845 .

The Bank of England evolved in a quite different manner. The Bank of England had distinct ties to the British parliament, and acts of parliament placed some restrictions against chartering other banks looking to compete. Adam Smith was completely aware of the Bank of England's connection to the British government, "It acts, not only as an ordinary bank, but as a great engine of state" (Smith 1776, 320). The Bank of England was regulated by, and formed a part of, the web of government interventions in Great Britain.

One important restriction that banks in England faced, but banks in Scotland did not, was the six-partner rule (Smith 1776, 320; West 1997, 128; White 1984, 40). The rule prevented banking companies from forming with more than six partners. The rule had a strong effect on potential competition with the Bank of England. The barrier to entry provided enough of a hurdle that banks could not create enough capital to become competitive. The result was a number of failed country banks.

Although the small country banks of England were failing, The Bank of England was operating just fine. The Bank of England was not issuing notes of any denomination 
less than $£ 10$ until a $£ 5$ note was issued in 1793 (White 1984, 39), but the country banks would regularly issue notes for much smaller sums. Thus, the issuing of small denomination notes quickly became associated with bank failures. Popular sentiment began to stand in favor of regulation against such small denomination notes as the public was upset about the bank failures (West 1997, 128; White 1984, 29 and 39).

In his most direct statements endorsing the regulation of small denomination notes, Smith seems to be mainly concerned with the failing country banks. He briefly mentions the small denomination notes previously issued by banks of Scotland, but then remarks that the act of 1765 put a stop to their circulation. Smith then goes on and states that in, "some paper currencies of Yorkshire, it was issued even for so small a sum as a sixpence" (Smith 1776, 322). Directly following this statement are the passages that are most commonly associated with Smith's support of this particular intervention. But what is Smith's recommendation for a restriction of banking notes referring to? Smith is stating that he is concerned with areas where these small sums are allowed and these are very small denominations such as a sixpence. The only banks that are issuing such small sums are the country banks. Often scholars look at Smith's cap on small denomination notes as an addition to the Scottish regulatory system, but keep in mind a sixpence was $1 / 40^{\text {th }}$ of the lowest legal amount issued in Scotland at the time $W N$ was printed. Smith's concern in these statements is clearly tied to these country banks that issue such small notes and have "frequent bankruptcies" - again something not common of the banks of Scotland. Smith is joining forces with popular sentiment against the common practices of 
the small and frequently failing country banks of England while trying to support Scotland's mostly free banking system.

Despite never directly attacking the system of banks in Scotland, Smith does give his endorsement to a potential addition to the level of intervention currently in place. The status quo of Scotland was to have no notes lower than $£ 1$ while the limit on English banks was $£ 10$. The bank of England, though it had $£ 10$ notes did not often issue anything less than $£ 20$. In fact, at the time any note of less than $£ 20$ was considered a novelty (Smith 1776, 322). Smith offers a compromise to the system between the two systems found in England and Scotland, "It were better, perhaps, that no bank notes were issued in any part of the kingdom for a smaller sum than five pounds" (Smith 1776, 323). Why would Smith make such a concession? It seems Smith is very worried about the failing banks and the regulations surrounding them and thus the level of his argument may not be his foundational desire but instead is the working with the particulars of his situation.

The public bias against these failing country banks made many feel the root problem was the low denomination values and Smith worked from with these particulars of the situation. The fact that Smith would use caution in this specific public policy issue is particularly telling as it was up for grabs throughout Smith's life. Based on Smith's arguments he does not seem to have any problems with the $£ 1$ restriction of Scotland, but in his most specific suggestion he sets the bar at $£ 5$ notes. With popular sentiment in England favoring The Bank of England's $£ 20$ notes instead of the much lower notes of the failing country banks, Smith seems to be attempting a compromise. So Smith's 
statement moves between the system of Scotland that capped anything less than $£ 1$ notes and the Bank of England which had a limit of $£ 10$ notes but more practically had a limit of $£ 20$ notes. Sentiment favored a high cap level on the issuing of bank notes and Smith states he is willing to have a moderate cap level which adds to the level in Scotland but detracted from the lowest value used by the Bank of England.

At the end of the chapter Smith reminds us where his focus lies. The real problem is the government involvement with banking institutions. In Smith's final paragraph on the matter he writes, "If bankers are restrained from issuing any circulating bank notes, or notes payable to the bearer, for less than a certain sum... their trade may, with safety to the publick, be rendered in all other respects perfectly free" (Smith 1776, 329). Smith is essentially telling his reader how they should favor the central issue of liberty in banking. Since there is serious unrest with the ideas he is tackling, he is willing to make concessions to the particular political circumstances of the day as long as they do not grow any further.

\section{Section 4, Part E: Questions Surrounding Smith’s Support of Usury}

Smith's support of the small denomination notes intervention ends with a rather clear statement about his general foundational beliefs. However, in the case of usury laws there has been much speculation about Smith's inconsistency without any clear statements pointing towards his foundational views in $W N$. Examining $W N$ does provide some clues as to how his take on usury may be a result of bargaining, much of the evidence comes from those around Smith. 
Smith's support of usury has been in doubt since it was first written. Both Dugald Stewart and Jeremy Bentham raise questions around Smith's arguments. For Stewart and possibly Bentham, it was not entirely clear that Smith actually supported the cap on usury despite the extended and fairly unequivocal arguments in WN. Some in Smith's day found it reasonable that much of the evidence points to the fact that Smith was comfortable with what he wrote in $W N$, but nonetheless privately desired a more liberal policy.

Publicly, Smith's support of usury laws demands that the interest rate be capped at a level slightly above "the lowest market price" (Smith 1776, 356). The suggestion he makes is not to prohibit usury, but to try to prevent loans at very high rates of interest. His suggestion is put forth as a way to avoid loans that only prodigals and projectors would be willing to take. To keep away from riskier loans Smith recommend's following Britain's status quo policy. He claims that Britain's policy is, "perhaps, as proper as any" (Smith 1776, 357). In WN Smith accepts intervention in the money lending market without much, if any, wavering from the arguments he put forth.

The doubt surrounding Smith's support of usury laws really starts with Bentham's Defence of Usury. The letters, originally published in 1787, helped put Jeremy Bentham's name on the map. He incisively argued against Smith's one paragraph justification of capping the interest rate. The actual arguments Bentham put forth aren't of concern here, but Bentham's approach highlights the inconsistent nature of Smith's take on usury. Bentham understood that Smith put forth a presumption of liberty that required the interventionist to bear the burden of proof and Smith did not meet that 
burden in propounding any intervention in usury. Thus, Bentham highlights Smith's inconsistency by stating, "I can see scarce any other way of convicting you of any error or oversight, than by judging you out of your own mouth" (Bentham 1787, 68). The inconsistencies highlighted by Bentham's critique open the door for one to question Smith's real desire for a cap on interest.

There is a bit of a folklore surrounding Smith's response to Bentham's critique. In The Life of Adam Smith the words of William Adam suggest that Smith "seemed to admit" that Bentham was correct in his critique. Bentham caught wind of the concession, but it seems that he never actually got direct confirmation from Smith himself. However, Bentham was confident enough of the information that he included a reference to it in an addendum to the letter. He wrote, "I have been flattered with the intelligence, that, upon the whole, your sentiments with respect to the points of difference are at the present the same as mine" (Smith 1776, 358). The addendum was written before Smith's final edits of $W N$, yet Smith never removed the paragraph Bentham criticized despite making other minor revisions to $W N$. The folklore surrounding Bentham's criticism certainly brings into question Smith's real feelings for the cap on interest.

One must also consider the veracity with which Smith originally put forth his support of usury laws. The section is a rather small overview of stock leant at interest. Only at the very end of the section does Smith consider legal restrictions on the rate of interest and his entire argument is captured in just a few paragraphs. Surrounding Smith's arguments for legal restrictions are warnings against laws that would completely prohibit interest. Smith does provide a paragraph explaining the reasons why the 
limitation on usury was needed. Hence, one cannot discount his arguments for usury laws all-together as though his only support is more like a throwaway line than his actual thoughts. However, the backing Smith provided was limited considering how starkly it contrasted with most of his general themes. Instead, Smith may have seen the hazard of a very harmful policy and he fought the particulars of that policy while still bargaining and making concessions from his central beliefs.

Dugald Stewart's biography of Adam Smith also points out Smith's weak and somewhat odd support of usury laws. It should be noted that the biography was put forth in a time of unease for Stewart. Due to the sedition trials, he was trying to show the moderation and neutrality of his own views and those attached to him - mainly Adam Smith's (Rothschild 2001, 56-58). Even despite Stewart's desire to show status quo loyalty, he still mentions Smith's odd support of usury laws in a footnote. Stewart calls Smith's take on usury “questionable" and claims Smith's ideas were presented with an "inconclusiveness of... reasoning" that was backed up only on "such slight grounds" (Smith 1980, 348). Stewart clearly questioned Smith's support of usury and seemed to wonder how Smith drew such conclusions.

Dugald Stewart finishes the footnote with a mention of John Locke's support of a legal rate of interest. Stewart notes that Locke supported a legal rate of interest even though all of his reasoning "point at the opposite conclusion" (Smith 1980, 349). Stewart ties together Smith's weak support for usury laws with Locke's making similar arguments about both author's approach to the subject. Stewart suggests that Locke's weak arguments could lead one to "suppose he was prevented [from pushing his 
arguments to its full extent] merely by a respect for established prejudices" (Smith 1980, 349). By partially tying together approaches of Smith and Locke, Stewart is indirectly acknowledging that Smith may have fudged his support of usury laws in a Solonesque attempt at appeasing the public bias. Stewart's biography and comments on John Locke further the folklore around Smith's real desire for usury laws.

With all the questions surrounding Smith's support of usury there is an opening for a Solonesque interpretation of Smith's support for an intervention. Usury restrictions are found in the highest ranked level of support from table 1. Thus, even in an instance that Smith most clearly supports an intervention in $W N$ there is a real possibility that Smith was strategically finding a way to seem less radical. In fact, with all the evidence provided here, it seems more likely that his support comes more as a politeness to the status quo than as a straightforward desire for intervention.

\section{Section 4, Part F: Conclusion to Section 4}

Smith's insistencies are very likely to be at least in part a result of picking the level of argumentation. It seems Smith choose his battles wisely. He did not always argue for his foundational ideals and often worked with the bias of the public's opinion on the particulars of issues. In the cases of education, the provision of roads, bridges, and canals, small denomination notes, and usury there is reason to believe Smith's inconsistencies are a result of his preference for selecting areas for a more compromising strategic approach. Smith believed in a level of politeness and respect for the status quo. He understood that at times one would argue for policy that was the best the people could 
bear. Thus, if Smith was astounded at a list of the interventions he supported, it would not be because of interventions such as roads, education, and banking. Smith's take on roads, education, and banking are likely a result of his Solonesque strategic approach and not mere slips of a deeper desire for intervention than he originally understood.

\section{Section 5: Smith and the Status Quo}

Although Adam Smith often presented soft or inconsistent recommendations for interventions, his system of natural liberty provided direct arguments against the poor policies of his day. If one looks more closely at Smith's interventions versus his proliberty arguments another difference is striking. When broken into two groups interventionist policy recommendations and liberalizing policy recommendations Smith's interventionist policy prescriptions are close to being direct restatements of the Scottish status quo. Smith never gave his support to a coercive policy that completely added a new intervention to the governance of Scotland.

Smith only talked favorably about an intervention if it already existed in the society in which he lived. He supported eighteen interventionist policies in $W N$. In every case the intervention was already in some similar form at work in Scotland. The only policy that went beyond the status quo of Scotland was already in place in England. In addition, Scotland had begun to make some concessions toward such reform and the foundation of the policy was already in place. By showing a respect towards the current bias regarding the governance of Scotland, Smith seems to be gently respecting the prejudice of other views while nonetheless attempting to push forward his radical ideas 
about political economy. As Jacob Viner stated, Smith made it clear that he had a "willingness to grant that those who saw things differently from [himself] were only partly wrong" (Viner 1927, 232). When Smith called for an intervention it was with the tone that Britain was already pretty much getting things correct, he never challenged for them to intervene more. However, Smith did challenge Britain to liberalize other policies.

Adam Smith's gentle approach with the status quo shows clear signs of Solonesque strategic writing. Smith made sure to moderate when necessary; he favored a radically free system, but he put forth his ideas in such a way that the temper of the population surrounding him could accept. Any other theories of Smith's approach must explain why his interventionist policy recommendations are stated as approvals of the status quo actions of government - never as additional types of intervention. Smith pointed to areas where he was willing to make some concessions in part to bring to light his willingness to put forth his system as a redirection and not a revolution of the status quo.

\section{Section 5, Part A: An Overview of Smith and the Status Quo Policies}

In order to back up such assertions, an overview of Smith's interventionist policies is needed. Appendix 2 provides a list of Smith's contraventions of natural liberty that have been pointed out by various scholars over time. Page numbers from $W N$ are given to provide a quick reference for recalling the essence of Smith's support. 
In many cases a scholar does not need to look any further than $W N$ itself to show that Smith's contraventions of natural liberty were in most cases very similar to the status quo. When discussing coinage by the government Smith states, "the government having every where the exclusive privilege of coining" (Smith 1776, 551). In his section on education he states, "In Scotland the establishment of such parish schools has taught almost the whole common people to read" (Smith 1776, 785). He talks of the current problems with the bridge, canal, and highway tolls which he supports, "In Great Britain, the abuses which the trustees have committed in the management of those tolls, have in many cases been very justly complained of" (Smith 1776, 726). The Navigation Acts he supports are clearly stated as the status quo, "The act of navigation, therefore, very properly endeavours to give the sailors and shipping of Great Britain the monopoly of the trade of their own country" (Smith 1776, 463-464). Smith's position on the in-kind payment requirements were already part of the government's restrictions: "The law which obliges the masters in several different trades to pay their workmen in money and not in goods, is quite just and equitable" (Smith 1776, 158). Similarly, examples could be given for Smith's discussion on strategic material bounties, small denomination notes, usury laws, party walls, options clauses, and mortgage registration. Adam Smith's interventions often draw attention to the status quo and take a conservative stance as opposed to making a call for further intervention.

In modern Smithian literature it often seems the norm to take Smith's interventions as serious steps away from his radical free market system and as pushes toward a more government regulation and interference. Thus, more argumentation and 
examination will be used to back the status quo claim. In addition to specific quotes and appendix mentioned previously, a few cases will be gone through to demonstrate that Smith was accepting the status quo and not trying to call for further interventions.

\section{Section 5, Part B: Joint Stock Companies and the Status Quo}

One very striking example of Smith's support of the status quo comes from analyzing his take on joint stock companies. Although it has already been argued that Smith severely limited the breadth of his support for joint stock companies, it is also important to realize what Smith limited his support to. His discussion strays in different directions, but his main emphasis is to limit the public application of joint stock companies to those already in place.

Smith supported the establishing of joint stock organizations to four public works: banks, insurance, canals, and water-supply. The only four domestic business activities that were already organized as joint stock companies without exclusive privileges prior to 1776 were banks, insurance, canals, and water supply (Scott 1968). Smith's main concern is the sovereign's ability to pick and choose which companies could become joint stock companies. For Smith to conclude that the only companies that could be selected to be joint stock companies are those that are already selected as joint stock companies should not go unnoticed. After all of Smith's attacks on the mercantilist policies of his day, it seems very coincidental that Smith concludes that the only four businesses that should meet the requirements for the joint stock venture would be the exact same businesses that are already undertaking them. Although Smith does provide 
rationale and reason for why those public works should have joint stock organization his reasoning seems tenuous at times. ${ }^{14}$

Basically, Smith had three requirements for joint stock companies. He wanted them to be routine, beneficial to the general populace, and capital intensive. The only organizations that Smith could conceive of meeting these three requirements were the ones that were already organized this way. Some other topics in $W N$ seem to meet these requirements such as roads, bridges, post offices, and possibly schooling. If one can find fault with these examples, it seems likely they can also find fault with Smith's own examples. His reasoning is not rigorous and seems passive and limited. Smith's arguments only mildly support his conclusions.

His meager support and coincidental support of only those companies that already existed strongly supports the idea that Smith tried to put forth some acceptance of the status quo. Smith wasn't going out on a limb in favor of intervention; he was reducing its scope down to that which was already in place. He gave acquiescent approval of the surviving domestic joint stock companies during his time.

\section{Section 5, Part C: Scottish Parish Schools}

A second, more highly contested, example of Smith's support of the status quo comes from analyzing his take on education. A 1696 Act of Scotland ordered landlords to build a schoolhouse and dwelling house for the use of the local master in every parish

\footnotetext{
${ }^{14}$ See (Smith 1776, 756) where he explains the simplicity of the banking and insurance industries. Others have also had issues with Smith's arguments that these businesses were routine (Anderson and Tollison 1982, 1244).
} 
(West 1964, 465). To Smith and many others the system seemed to be working relatively well, "it was commonly observed that both in quality and quantity the schools in Scotland were better than those in England, despite the superior material prosperity of the latter" (West 1964, 465). Overall, the Scottish system surpassed the performance of the English system. The English schools utilizing the endowment system were crowding out their more productive private schools and the English system was continually found lacking when compared to that of Scotland. Although taking a pro-interventionist position and disapproving of the English system, Smith's strategic approach is still rooted in approval of the Scottish the status quo.

Smith's support for the Scottish parochial system stemmed mainly from the teacher's being paid by the consumers of their services. In large part the school house was provided by the local funds, whereas families paid the majority of the teacher's salaries. Smith was willing to accept this modest level of intervention because it avoided his main concern of an endowment funding entrenching poor education for the youth. When Smith argued for any kind of intervention in education the idea of user fees always were central. The problem to avoid was one with no incentives for the students or teachers. Thus, Smith despised the idea of the endowment system or completely subsidized education. Instead, Smith's pro-interventionist arguments within his section on education show a support for the Scottish status quo. 


\section{Section 5, Part D: Small Denomination Notes}

There is one case where Smith clearly adds to the level of intervention of Scotland. Although Smith does not suggest a new type of intervention he does allow for a more binding level of restriction. The status quo of Scotland was to have no notes lower than $£ 1$. Yet, Adam Smith suggests that "It were better, perhaps, that no bank notes were issued in any part of the kingdom for a smaller sum than five pounds" (Smith 1776, 323). If Smith clearly added to the level of intervention, how could it be argued that he had any tie to the status quo?

Adam Smith did add to the level of the intervention, but he was working with the interventionist policies already in place. The limit on small denomination notes was already $£ 1$ in Scotland and while a move up to $£ 5$ seems drastic, it must be understood in context. Smith's call is for the entire kingdom of Great Britain and his main concern is to push for a banking regulatory system that closely mimics what is in place in Scotland. The limit on small denomination notes in English banks was $£ 10$, and in reality very few notes were issued for anything less than $£ 20$.

The main problem for Smith was the public unrest with the failing country banks in England. These banks issued notes with much smaller denominations than legally allowed in Scotland. The Bank of England was an integrated part of the political system and was not issuing such small notes, but the six-partners rule caused other banks to have problems with garnering enough capital to become viable. The country banks of England, with their lack of capital, were failing far too frequently and causing the public to become discontent. What was Smith's solution? Smith came down on the side of compromise. 
He suggested that the practice in Scotland was heading in the right direction but he added to the level of the intervention while still remaining more liberal than the general practice in England.

Smith could have argued against the six-partners rule in England, but choose instead to only compromise with the much more popular discontent against small denomination notes. The six-partner rule may have been a political battle that was far too challenging for Smith to battle, as Smith does refer to the Bank of England as a "great engine of state" (Smith 1776, 320). However, Smith's omission of any direct argument against the six-partner rule does make Smith's stance show a fair amount of acceptance and compromise.

Although Smith provided a suggested solution to failures of the English country banks that would have been an increase to the level of intervention in Scotland, he clearly remained very partial to the Scottish system. When studying the free banking institutions of Scotland, Lawrence White writes, “Smith's policy conclusion at the chapter's end was simply an endorsement of the status quo of Scotland" (White 1984, 54). The real problem was the government involvement with banking institutions. In Smith's final paragraph on the matter he writes, "If bankers are restrained from issuing any circulating bank notes, or notes payable to the bearer, for less than a certain sum... their trade may, with safety to the publick, be rendered in all other respects perfectly free" (Smith 1776, 329). Smith is telling his reader to favor the central issue of liberty in banking.

Smith supported the Scottish banking system, but was willing to compromise with the popular prejudice of his day and would potentially be willing to increase the level of 
regulation on banking notes. This is the one case where one can argue that Smith adds to the level of intervention found in Scotland, but it also seems very plausible that he is doing so in order to prevent a larger increase in the level of intervention. The Bank of England for the most part had minimal notes of $£ 20$. Either way, the tie between Smith’s interventionist recommendations and the status quo remains quite strong.

\section{Section 5, Part E: Smith the Scotsman}

One can examine all of Smith's interventionist policy suggestions and see ties to the status quo of his day. His interventionist suggestions highlight his British, and more specifically his Scottish, roots. Although Smith's recommendations mirror many of the British status quo policies it seems clear that Smith was especially proud of what was taking place in the Scottish part of the kingdom.

After the union of Scotland and England in 1707 Great Britain's Parliament largely ignored the Scottish people. The Parliament left the Scottish land free to develop without much economic interference and yet protected by a strong administrative state (Herman 2001, 59). During the half century following the union the economic circumstances of the Scottish people improved immensely. Adam Smith observed the growth of his nation and felt more or less that the Scots were getting things right. When Jacob Viner reflects back on Smith's general approach he concluded similarly,

While Smith was a keen observer of his surroundings and used skillfully what he saw to illustrate his general arguments, his loyalties were primarily to the Britain of which Scotland was for him an integral part, not a colony or subordinate partner. 
For Adam Smith, the land in Britain to follow was Scotland - a land with a fair amount of liberty.

Although Smith was most impressed with the liberal policies of Scotland he also took pride in the governing rule of Britain generally. He certainly stood opposed to many policies in Britain, but Smith's $W N$ was not an attempt at a complete reformation or revolutionary shift. For Smith, the status quo of Britain had its imperfections, but Smith could find ways to sympathize with the current policies as for the most part things were going relatively well. The administration of Britain was tolerable and in WN Smith found ways to highlight the areas of British policy that were acceptable.

The fact that Adam Smith's interventionist suggestions aligned with the British status quo gave Smith credibility that an uncompromising partisan of liberty could not acquire. He showed that his system stood opposed to much of the problems in the land while still maintaining a sense of camaraderie by showing that his system was just an improvement on the British system and not a revolutionary step away from it. His support of the Navigation Acts promoted the Royal Navy - the pride of the nation. His reception of the current corn export restrictions showed compromise. And, his tacit assent of arrangements in coinage and the post office helped keep him an ally of the people. Overall, Smith's interventionist suggestions were moments of Smith planting himself as a partial supporter of the status quo.

The political bias of the public was important to Smith. His respect for the impact of the public prejudice is encompassed throughout his work (Clark 2011). The respect he gave toward the public prejudice shined through his writing style, and the approach 
enhanced the size of Smith's audience. The fact that the everyman in Scotland had books and read them surely wasn't lost on Smith $^{15}$ (Herman 2001, 26). Smith would be a cautious critic of Britain. His approach was to honor the land that he respected for being relatively right, yet to still put forth his general thoughts and ideas.

When Smith's policies are broken up into interventionist suggestions and liberal suggestions, the interventionist suggestions align almost perfectly with the status quo of Smith's day. The fact that Smith's interventionist moments match up with the status quo show his concerns for the way his words were received. As Dugald Stewart said, Smith was "cautious with respect to the practical application of general principles" (Smith 1980, 318). His interventions often draw attention to the status quo and take a conservative stance as opposed to making a call for further intervention. Smith had a deep foundational appreciation for liberty, but he made sure to respect the reality of the system already in place around him. Smith's WN approved of intervention perhaps $10 \%$ of the time, but Smith's respect for the status quo most likely caused an inflation of that number from Smith's true preferences. Any other theories of Smith's ideological outlook must explain why his interventionist policy recommendations are stated as approvals of the status quo actions of government - never as additional types of intervention.

\section{Section 5, Part F: Potential Arguments Against the Status Quo Argument}

One objection that could be raised is that Smith was simply looking at the interventions in the world around him. He was familiar with the policies of his homeland

\footnotetext{
${ }^{15}$ See (Herman 2001, 23-26) for more on Scotland's use of books in the $18^{\text {th }}$ century.
} 
so he kept his discussion limited to the merits of the interventionist policies of Scotland. However, Smith was keenly aware of other systems of government and was traveling while writing the $W N$ (Holdsworth 1935, 537). He was well studied and had insight to other systems of governance from his peers, in particular those in France. He was also able to write about the economic history of Spain, Portugal, and China to go along with his many references to the classics. Smith had the ammunition to promote interventionist policy that was not Scottish in origin, but he never fired that gun.

The objection that Smith was just taking the interventions around him doesn't match the evidence found in the $W N$. In fact, since we are aware that Smith took such universal input for the formation of his ideas in the $W N$ it makes it all the more pertinent and astonishing that Smith didn't challenge the Scottish status quo for any interventionist policies. Although Smith did explicitly attack some of Scotland's interventionist policies in the name of natural liberty, he made it possible to be Scottish and be proud to read the $W N$. He seems to be pushing the idea that his peers and countrymen were moving their political culture and institutions in the right direction.

It is quite clear that Smith had input from beyond the Scottish experience. However, the argument that Smith is using a strategic approach like that of Solon could be countered by showing that Smith was merely always supporting the status quo. If Smith's free market opinions never countered policies already in place then an interpretation of Smith as a conservative gains credence. In addition, if Smith always supports the status quo, then examining his use of status quo rhetoric when supporting interventions becomes a moot point. 
Smith did not put forth his ideas as an acceptance of the Scots status quo. Smith was frequently very forthright in exploring the benefits of liberty and the problems with intervention. Even Gavin Kennedy, who, in my view, overstates Smith's interventionism, admits that Smith's rhetoric was regularly let loose upon the spendthrift governments and improper management of failing mercantile enterprises (Kennedy 2008, 9 and 189-190) and denounces "the assault of the statutes on perfect liberty in the most uncompromising terms" (Kennedy 2008, 142). The core of Smith's ideas set up the liberty principle or the presumption of liberty. The presumption of liberty presumes liberty is the best policy unless there are very persuasive reasons to make a special exception. Although Smith did not always specifically challenge the status quo policies of Britain, his ideas lined up directly opposed to policies that benefited special groups and not the populace as a whole.

The initial interpretation of Smith was as a rather radically liberal author (Tribe 1999, 613). Smith's peers received him as a friend of liberty and read $W N$ as a tract that supported his liberal views. Smith's reputation remained largely intact for well over a hundred years but the modern interpretation of his works is now challenging that interpretation.

Gavin Kennedy argues that Viner's 1927 conclusion that Smith was not a doctrinaire believer in Laissez-Faire shows the seemingly bizarre nature of $W N$ 's reputation over the years. Kennedy argues that the fact that Viner "needed to write this 150 years after Wealth of Nations... suggests that a substantial drift away from important elements of Smith's legacy had taken place among early-20 $0^{\text {th }}$-century economists" 
(Kennedy 2008, 248). One could interpret the 150 year lack of attention to Smith's concessions to natural liberty as shocking. But, it seems more likely that the original interpretation of Smith is more accurate. Smith may have pockets of supporters who believe he is in favor of liberty no matter the cost, but they are few and far between. Arguing against such interpretations of Smith is fighting a straw man. Kennedy argues that Smith is not a doctrinaire supporter of liberty and that liberty is not Smith's sole goal. But again, these are straw man arguments. The 150 year lack of attention to Smith's more interventionist side isn't shocking; it is to be expected. Adam Smith's focus was on the system of natural liberty, it is a modern scholastic exercise to focus on anything else.

\section{Section 5, Part G: Conclusion to Section 5}

Adam Smith made sure to respect the British status quo, but he surely did not support a purely conservative approach. In his personal correspondence he admitted that the logic of his system extended out to be a "very violent attack... upon the whole commercial system of Great Britain" (Smith 1977, 251). This statement, in conjunction with the idea that Smith never lends support for a new intervention in Britain, only makes sense when one views Smith as taking the strategic approach of Solon. The quote shows that in private writings Smith was willing to discuss the radical implications of his work. However, within his public writings, such as the $W N$, the violence of his attack was downplayed. Nowhere in $W N$ does Smith call his work anything like a violent attack on 
Britain. Instead, the public Smith was Solonesque and used rhetoric that showed his nation how wealth was created.

Smith followed the sentiments of Solon by couching his arguments in terms that were the best the people of his time could bare. He allayed concerns about his radical theories by showing he was in agreement with some interventionist policies. Despite never arguing for a new interventionist policy, Smith aided the ease with which the people could accept his ideas and recommendations by allowing them to keep their selfimage of being good, fair minded citizens. Smith believed that the liberty principle should guide decisions about society, but he also showed that the system had exceptions. Smith strongly put forth his system of natural liberty, but he also allayed concerns about just how radical it was.

Smith was careful enough in $W N$ that his work ended up meeting the public with relative acceptance. In his private letter to Andreas Holt, Smith notes he and his work had "upon the whole been much less abused than I had reason to expect" (Smith 1977, 251). This private letter not only acknowledges that Smith was aware of the bias against his claims, but it also shows that Smith's caution paid off. Smith felt that his work had not crossed the line.

Adam Smith felt that he had apparently not pushed the fine line of public prejudice versus his personal ideas to its limit. He admitted as much in 1780 to Andreas Holt. He backed up his words to Holt with his actions in 1784 when he created the third edition of $W N$. In a letter discussing the third edition, Smith writes to William Strahan,

This edition will probably see me out and I should therefore chuse to leave it behind me as perfect as I can make it. The Principal additions are to the 
second Volume. Some new arguments against the corn bounty; against the herring buss bounty; a new concluding Chapter upon the mercantile System; A short History and, I presume, a full exposition of the Absurdity and hurtfulness of almost all our chartered trading companies.

The reception of Smith's masterpiece allowed Smith to make changes to the text so that they more closely resembled his true feelings and preferences. From Smith's additions and private statements it seems that there is no other explanation than the idea that Smith's system was put forth in a cautious and Solonesque fashion.

\section{Section 6: Conclusion}

The interventions Smith supported have been catalogued and shown to have only a moderate level of support. In addition, the mollifying tone in Smith's work has been highlighted in three major ways. First, a number of cases where Smith called for a break with natural liberty were done so using reasoning that seemed sincere, but still tried to provide some affirmation to a liberty principle. Second, Smith was shown to have periods of inconsistencies as a result of Smith moving from challenging foundational issues to bargaining with particular policies. And finally, Smith did not really attempt to add to the status quo intervention of Scotland and England, instead it appeared he was just accepting some of the interventions already in place. The evidence does not deny most of Smith's interventionist moments, but it brings into question his actual level of support for interventionist policies in general.

Jacob Viner's statement that Smith would be astounded at his own moderation if he was shown a list of his interventions misses the essence of Smith's work. Smith's approach, the approach of Solon (Clark 2011), pushed Smith toward moderation when 
necessary. In $W N$ there are many signs that Smith took a Solonesque approach. Smith's interventionist public policy views take soft stances, create little to no additional interventions to the status quo, or are put forth in such a way as to make his liberal framework seem amenable to those who hold a more popular or normal worldview. The weak or compromising characteristics of Smith's interventionist policies fit in well with his more theoretical statements about the desire to work with public prejudice. Smith practiced what he preached about putting forth policies that were the best the people could bare. But, would Smith have been astounded at his own moderation? Maybe, but Smith would have understood it as just that - moderation to public prejudice. 


\begin{tabular}{|c|c|c|c|}
\hline $\begin{array}{l}\text { Word } \\
\text { Searched }\end{array}$ & $\begin{array}{l}\text { Sound or } \\
\text { Movement } \\
\text { Metaphor }\end{array}$ & $\begin{array}{l}\text { Number of } \\
\text { Corresponding } \\
\text { and Relevant } \\
\text { Passages }\end{array}$ & $\begin{array}{l}\text { Pages Where the Word } \\
\text { Appears (Page.Paragraph) }\end{array}$ \\
\hline Accord & Sound & 2 & $238.5,268.8$ \\
\hline Accordance & None & 0 & \\
\hline Beat (sound) & None & 0 & \\
\hline Beat Time & Movement & 3 & $21.7,69.3,73.1$ \\
\hline Beating & None & 0 & \\
\hline Beats Time & Movement & 1 & 70.5 \\
\hline Cacophonous & None & 0 & \\
\hline Cacophony & None & 0 & \\
\hline Chant & None & 0 & \\
\hline Chanting & None & 0 & \\
\hline Chants & None & 0 & \\
\hline Chord & None & 0 & \\
\hline Choreograph & None & 0 & \\
\hline Choreographed & None & 0 & \\
\hline Choreography & None & 0 & \\
\hline Chorus & None & 0 & \\
\hline Concord & Sound & 12 & $\begin{array}{l}16,16.1,21.7,22.8,45.6 \\
78.11,95.4,187.2,190.9 \\
222.12,268.8,281.28\end{array}$ \\
\hline Concordance & None & 0 & \\
\hline Consonance & None & 0 & \\
\hline Consonancy & None & 0 & \\
\hline Dance & None & 0 & \\
\hline Dances & Movement & 1 & 43.2 \\
\hline Dancing & None & 0 & \\
\hline Discord & Sound & 3 & $220.5,222.12,232.13$ \\
\hline Discordant & Sound & 4 & $36.5,37.6,37.7,86.3$ \\
\hline Disharmonic & None & 0 & \\
\hline
\end{tabular}




\begin{tabular}{|c|c|c|c|}
\hline $\begin{array}{l}\text { Word } \\
\text { Searched }\end{array}$ & $\begin{array}{l}\text { Sound or } \\
\text { Movement } \\
\text { Metaphor }\end{array}$ & $\begin{array}{l}\text { Number of } \\
\text { Corresponding } \\
\text { and Relevant } \\
\text { Passages }\end{array}$ & $\begin{array}{l}\text { Pages Where the Word } \\
\text { Appears (Page.Paragraph) }\end{array}$ \\
\hline Disharmonious & None & 0 & \\
\hline Disharmony & None & 0 & \\
\hline Dissonance & Sound & 2 & $16,16.1$ \\
\hline Drum & None & 0 & \\
\hline Drumming & None & 0 & \\
\hline Harmonics & None & 0 & \\
\hline Harmonious & Movement & 2 & $183.9,316.2$ \\
\hline Harmony & $\begin{array}{l}\text { Sound and } \\
\text { Movement }\end{array}$ & $\begin{array}{l}14 \text { Sound, } 1 \\
\text { Movement }\end{array}$ & $\begin{array}{l}\text { 19.2, 20.5, 21.7, 25.5, 38.1, } \\
39.2,43.2,45.6,78.11,85.4, \\
125.22,145.23,185.11, \\
268.8,337.28\end{array}$ \\
\hline Keep Time & $\begin{array}{l}\text { Sound and } \\
\text { Movement }\end{array}$ & $\begin{array}{l}2 \text { Sound, } 3 \\
\text { Movement }\end{array}$ & $\begin{array}{l}27.1,30.12,45.8,76.8, \\
337.28\end{array}$ \\
\hline Keeping time & Movement & 1 & 47.12 \\
\hline Keeps Time & Sound & 1 & 16.1 \\
\hline Kept (time) & None & 0 & \\
\hline March & None & 0 & \\
\hline Marching & None & 0 & \\
\hline Melodic & None & 0 & \\
\hline Melodically & None & 0 & \\
\hline Melodies & None & 0 & \\
\hline Melodious & Sound & 1 & 37.6 \\
\hline Melody & None & 0 & \\
\hline Meter & None & 0 & \\
\hline Motion & Movement & 2 & $185.11,233.17$ \\
\hline Move & Movement & 1 & 185.11 \\
\hline Movement & Movement & 2 & $50.1,316.2$ \\
\hline Moving & None & 0 & \\
\hline Music & Sound & 1 & 37.6 \\
\hline Musical & Sound & 2 & $37.6,337.28$ \\
\hline Pitch & Sound & 7 & $\begin{array}{l}21.7,22.9,25.8,27.1,34.1 \\
45.8,337.28\end{array}$ \\
\hline Rhythm & None & 0 & \\
\hline
\end{tabular}




\begin{tabular}{|l|l|l|l|}
\hline $\begin{array}{l}\text { Word } \\
\text { Searched }\end{array}$ & $\begin{array}{l}\text { Sound or } \\
\text { Movement } \\
\text { Metaphor }\end{array}$ & $\begin{array}{l}\text { Number of } \\
\text { Corresponding } \\
\text { and Relevant } \\
\text { Passages }\end{array}$ & $\begin{array}{l}\text { Pages Where the Word } \\
\text { Appears (Page.Paragraph) }\end{array}$ \\
\hline Rhythmic & None & 0 & \\
\hline Sing & Sound & 1 & 205.9 \\
\hline Singing & None & 0 & \\
\hline Sings & None & 0 & $205.9,281.28,283.30$ \\
\hline Song & Sound & 3 & \\
\hline Sound & None & 0 & \\
\hline Sounds & None & 0 & \\
\hline Step & None & 0 & \\
\hline Stepping & None & 0 & \\
\hline Stomp & None & 0 & \\
\hline Stomping & None & 0 & \\
\hline Sung & None & 0 & \\
\hline Sync & None & 0 & \\
\hline Synchronous & None & 0 & \\
\hline Synchrony & None & 0 & \\
\hline Tempo & None & 0 & \\
\hline Timbre & None & 0 & \\
\hline Tone & Sound & 2 & \\
\hline Tune & Sound & 1 & \\
\hline Tuned & None & 0 & \\
\hline Tunes & None & 0 & \\
\hline Unharmonious & None & 0 & \\
\hline Unison & None & 0 & \\
\hline Unisons & Sound & 1 & \\
\hline Unmelodic & None & 0 & \\
\hline Unmelodious & None & 0 & \\
\hline & & & \\
\hline
\end{tabular}




\section{APPENDIX 2: SMITH'S INTERVENTIONS}

\begin{tabular}{|c|c|}
\hline Intervention & Pages \\
\hline Canals and Harbors & $163-164,724-731,756-758$ \\
\hline Coinage & $71-64,301-303,478-480,549-555$, \\
\hline Corn Export Restrictions & $524-543$ \\
\hline Education & $758-815$ \\
\hline High Roads & $724-731$ \\
\hline Joint Stock Companies & $732-758$ \\
\hline Leprosy & $787-788$ \\
\hline Mortgage Registration & 863 \\
\hline Navigation Acts & $325-329$ \\
\hline Options Clause & 324 \\
\hline Party Walls & $157-158$ \\
\hline Payment-In-Kind & 724,818 \\
\hline Post Office & $320-329$ \\
\hline Roads & $522-533$ \\
\hline Small Denomination Notes & $733,754-755$ \\
\hline Strategic Material Bounties & $350-359$ \\
\hline Temporary Monopolies & $164,724-731,815$ \\
\hline Usury & \\
\hline
\end{tabular}




\section{LIST OF REFERENCES}

Anderson, Gary and Tollison, Robert. 1982. “Adam Smith's Analysis of Joint Stock Companies,” The Journal of Political Economy. Vol. 90, No. 6. Pg. 1237-1256.

Bentham, Jeremy. 1787. "Gulphs in Mankind's Career of Prosperity: A Critique of Adam Smith on Interest Rate Restrictions," Preface by Dan Klein 2008. Econ Journal Watch. Vol. 5, No. 1. Pg. 66-77.

Clark, Michael. 2011. "The Virtuous Discourse of Adam Smith: A Liberal Regard for Prevailing Prejudice," Working Paper. http://mercatus.org/publication/virtuousdiscourse-adam-smith.

Fleischacker, Samuel. 2004. On Adam Smith's Wealth of Nations. Princeton University Press.

Friedman, Milton. 1975. "Adam Smith's Relevance for 1976," International Institution for Economic Research Original Paper. Selected Papers No. 50. Los Angeles.

Herman, Arthur. 2001. How the Scots Invented the Modern World: The True Story of How Western Europe's Poorest Nation Created Our World and Everything in It. Three Rivers Press. New York, New York.

Holdsworth, W.S. 1935. "The Importance of Adam Smith's Wealth of nations in English Legal History," The University of Chicago Law Review. Vol. 2, No. 4. Pg. 533-551.

Hollander, Samuel. 1979. "Review of Adam Smith's Politics: An Essay in Historiographic Revision by Donald Winch," Journal of Economic Literature, Vol. 17, No. 2: 542-545.

Klein, Daniel and Clark, Michael. 2010. "Direct and Overall Liberty: Areas and Extent of Disagreement," Reason Papers.

Kennedy, Gavin. 2008. Adam Smith: A Moral Philosopher and His Political Economy. Palgrave Macmillan.

McLean, Iain. 2006. Adam Smith: Radical and Egalitarian. Edinburgh University Press.

Rothschild, Emma. 2001. Economic Sentiments: Adam Smith, Condorcet, and the Enlightenment. Harvard University Press.

Scott, William R. 1968. The Constitution and Finance of English, Scottish and Irish Joint-Stock Companies to 1720. Vol. 1. 1912. Reprint. Gloucester, Mass. 
Smith, Adam. 1776. An Inquiry into the Nature and Causes of the Wealth of Nations. Edited by R.H. Campbell, A.S. Skinner and W.B. Todd. Oxford University Press/Liberty Fund Edition. 1976.

Smith, Adam. 1977. The Correspondence of Adam Smith. Edited by E.C. Mossner and I.S. Ross. Oxford University Press/Liberty Fund Edition.

Smith, Adam. 1980. Essays on Philosophical Subjects. Edited by W.P.D. Wightman. Oxford University Press/Liberty Fund Edition.

Stanfield, James. 2005. "Adam Smith on Education," Institute of Economic Affairs. Blackwell Publishing. Oxford, England.

Steele, Shelby. 1990. The Content of Our Character: A New Vision of Race in America. Copyright by Shelby Steele.

Stigler, George. 1965. "The Economist and the State," The American Economic Review. Volume LV, No. 1. Pg. 1-18.

Teichgraeber III, Richard. 1981."Rethinking Das Adam Smith Problem," The Journal of British Studies. Vol. 20, No.2. Pg. 106-123.

Tribe, Keith. 1999. “Adam Smith: Critical Theorist?” Journal of Economic Literature, Vol. 37, No. 2: 609-632.

Viner, Jacob. 1927. "Adam Smith and Laissez-Faire," Journal of Political Economy. Vol. 35, No. 2. Pg. 198-232.

Viner, Jacob. 1965. Guide to John Rae's Life of Adam Smith. New York: Augustus M. Kelley.

West, E.G. 1964. "Private Versus Public Education: A Classical Economic Dispute," Journal of Political Economy. Vol. 72, No. 5.

West, E.G. 1977. "Adam Smith's Public Economics: A Re-Evaluation," The Canadian Journal of Economics. Vol. 10, No. 1. Pg. 1-18.

West, E. G. 1997. “Adam Smith's Support for Money and Banking Regulation: A Case of Inconsistency," Journal of Money, Credit and Banking. Vol. 29, No. 1, pages 127-134.

White, Lawrence. 1984. Free Banking in Britain. Cambridge University Press. 